\title{
THE FORGOTTEN EQUALITY NORM IN IMMIGRATION PREEMPTION: DISCRIMINATION, HARASSMENT, AND THE CIVIL RIGHTS ACT OF 1870
}

\author{
LUCAS GUTTENTAG*
}

This Article explores the importance of the Civil Rights Act of 1870 to the current debate over immigration federalism and the preemption of state and local immigration laws under the Supremacy Clause. The 1870 Act, enacted by the Reconstruction Congress after the Civil War, prohibits discrimination on the basis of "alienage." The Article shows that the Act's protections are an essential component of the federal framework limiting sub-federal immigration laws. In Arizona v. United States, the Supreme Court found key parts of Arizona's SB 1070 immigration enforcement act preempted. The Court focused on the federal government's broad authority to enforce the immigration act, to set enforcement priorities, and to determine the terms and conditions for the admission and expulsion of foreign nationals. The author refers to this as the "immigration control" basis for preemption.

The Article explains that the immigration control element is important but incomplete. That focus omits consideration of the separate and additional source of federal primacy derived from the Civil Rights Act of 1870 that the author calls the "immigrant equality" basis for preemption. The Article discusses the origins of the Act's protections, their subsequent codification, and the Supreme Court's reliance on the Act's anti-discrimination mandate in immigration preemption cases

* Robina Foundation Distinguished Senior Fellow in Residence, Ford Foundation Distinguished Research Scholar, and Lecturer in Law, Yale Law School; Lecturer in Law, Stanford Law School; founder and former national director, American Civil Liberties Union Immigrants' Rights Project. This Article grew out of a lecture at Duke University School of Law sponsored by the Duke Journal of Constitutional Law and Public Policy and the Keenan Center on Ethics. I am grateful for helpful comments on the ideas developed here or on earlier drafts from conference participants David Martin and Hiroshi Motomura, and from Lee Gelernt, Robert Gordon, Omar Jadwat, Michael McConnell, Jennifer Chang Newell, and Judith Resnik. Katherine Austin provided stellar research and assistance as did Mia Crager. Charanya Krishnaswami, Anuj Nadadur, Joshua Rosenthal, Travis Silva, Xiao Wang, and Elizabeth Wilkins all contributed in multiple ways. All conclusions, mistakes, and omissions are of course my own. An initial version of the thoughts expressed in this Article appeared in Lucas Guttentag, Discrimination, Preemption, and Arizona's Immigration Law: A Broader View, 65 STAN. L. REV. ONLINE 1 (2012) [hereinafter Guttentag, Discrimination]. 
over the course of nearly a century. The Article argues that recognizing immigrant equality as a source of federal supremacy has significant consequences for immigration federalism. The equality principle assesses the discriminatory consequences of sub-federal immigration measures and draws a fundamental distinction between measures that further immigrant equality (often referred to as "sanctuary" ordinances) and laws that threaten to engender discrimination (like SB 1070). The Article concludes that robust federal supremacy barring punitive immigration enforcement laws can easily coexist with ample leeway for states and localities to adopt immigrant protection laws that safeguard non-citizens in municipal life.

\section{INTRODUCTION}

State and local immigration laws pit claims of federal primacy against assertions of state autonomy. In Arizona v. United States, ${ }^{1}$ the Supreme Court adopted a muscular view of federal immigration supremacy to strike down essential parts of an Arizona law aimed at Arizona's undocumented immigrants. After a lull of many decades in the Court's immigration preemption jurisprudence, the Supremacy Clause reemerged powerfully to limit state immigration legislation. ${ }^{2}$

The Supreme Court's displacement of state law was rooted in the complexities of the immigration statute, Arizona's potential intrusion into foreign relations, and the federal government's power to set immigration enforcement priorities. Arizona held that central parts of the state legislation, popularly known as SB 1070, were inconsistent with the strictures of the Immigration and Nationality Act (INA) and with the enforcement discretion vested in the Executive Branch. The Court read federal law as erecting a de facto federal ceiling on immigration enforcement that state laws cannot exceed.

The Arizona decision recognized one element of the federal framework governing immigrants and immigration. The Court robustly validated the federal government's broad authority to enforce the immigration statutes, to set federal immigration enforcement policies, and to determine the terms and conditions on which foreign nationals are admitted to and expelled from the United States. This basis for federal immigration preemption is grounded in

1. 132 S. Ct. 2492 (2012).

2. Outside the immigration-specific context, the Supremacy Clause and preemption have featured prominently in Supreme Court decisions of recent years. For an excellent discussion, see, for example, Ernest Young, "The Ordinary Diet of the Law": The Presumption Against Preemption in the Roberts Court, 2011 SUP. CT. REV. 253 (2012) (providing a comprehensive review of preemption doctrine in the Roberts Court). My focus is limited to the scope of preemption with respect to sub-federal immigration measures. 
notions of sovereignty and enforcement that confer vast authority on the political branches to set immigration policy. I refer to it as the "immigration control" or "control" component of immigration preemption.

Absent from Arizona, however, is a second and separate ground for limiting state immigration policies that has long served as a source for preemption of sub-federal laws. This basis for preemption is rooted in the longstanding federal prohibitions against state "alienage" discrimination that require equality of treatment between citizens and "aliens" across a wide spectrum of civic life. The source of this federal protection is the historic Civil Rights Act of 1870 enacted by the Reconstruction Congress after the Civil War. ${ }^{3}$ The 1870 Act consciously outlawed discriminatory state immigration laws to protect unpopular non-citizens of that era. Over the ensuing century, the Supreme Court recognized the 1870 Act as an important factor in defining the federal interests that preempt state immigration legislation under the Supremacy Clause. I refer to this as the "immigrant equality" or "equality" component of federal immigration preemption.

In recent decades, the preemptive force of the 1870 Act-and of the immigrant equality component of immigration preemption-has been largely overlooked or forgotten. My purpose is to reinvigorate the importance of the 1870 Act as a source for preemption of subfederal immigration measures. I believe that restoring the role of the Civil Rights Act of 1870 is necessary to a proper understanding of the federal framework governing immigration and immigrants-and hence to defining the limits of immigration federalism.

The purpose of preemption is to enforce the "clear and manifest purpose of Congress." In the immigration context, the Supreme Court has explained that the Supremacy Clause bars sub-federal measures that "stand[] as an obstacle to the accomplishment and execution of the full purposes and objectives of Congress" $" 5$ and that it ensures local compliance with the country's "overriding national policies" with respect to foreign nationals. The Civil Rights Act of

3. Civil Rights Act of 1870, ch. 114, §§ 16-17, 16 Stat. 140, 144.

4. Arizona, 132 S. Ct. at 2501 (quoting Rice v. Santa Fe Elevator Corp., 331 U.S. 218, 230 (1947)). See Sprietsma v. Mercury Marine, 537 U.S. 51, 64-65 (2002); Crosby v. Nat'l Foreign Trade Council, 530 U.S. 363, 373 (2002); Caleb Nelson, Preemption, 86 VA. L. REV. 225, 228 (2000).

5. Arizona, 132 S. Ct. at 2501 (quoting Hines v. Davidowitz, 312 U.S. 52, 67 (1941)).

6. Graham v. Richardson, 403 U.S. 365, 378 (1971). The focus here is implied preemption. 
1870 is an integral part of those national policies, and the immigrant equality principle must stand on equal footing with other aspects of federal law if the "full purposes and objectives" of our "overriding national policies" are to be enforced.

Fully recognizing the immigrant equality component of the federal framework has practical implications for the current immigration federalism debate and gives greater normative content to federal limits on state authority. Embracing immigrant equality as a federal objective also helps to distinguish between two types of contemporary sub-federal immigration measures. Those local laws that increase discrimination against immigrants are at odds with the immigrant equality goal, whereas those local measures that diminish discrimination and advance immigrant integration or protection (often confusingly referred to as "sanctuary" laws) further that federal objective.

My claim is not that immigrant equality trumps all other considerations or dictates the outcome of every immigration preemption question. Rather, I argue that immigrant equality is an essential-and forgotten-ingredient in contemporary Supremacy Clause analysis. Courts should revitalize the equality norm in deciding whether a particular state immigration provision impedes federal interests or hinders federal goals. Failing to give sufficient weight to immigrant equality leads to an impoverished conception of the objectives of Congress in the immigration realm.

This Article proceeds as follows. Part I briefly describes Arizona v. United States to illustrate how the Court's preemption ruling rested on an immigration control view of the federal interest. Part II examines the basis for the immigrant equality component of federal immigration preemption. I first explain the origins of the 1870 Civil Rights Act's prohibitions against sub-federal alienage discrimination. I then review the role of the 1870 Act in the Court's immigration federalism rulings-bookended by Yick Wo v. Hopkins ${ }^{7}$ in 1886 and Graham v. Richardson ${ }^{8}$ in 1971-that recognize the equality mandate in the $1870 \mathrm{Act}$ as an important ingredient in federal preemption of state laws.

I do not address the more straightforward preemption inquiry where sub-federal regulation is barred under an express preemption clause or as an impermissible regulation of immigration interfering with exclusive federal power. See DeCanas v. Bica, 424 U.S. 351, 354 (1976).

7. 118 U.S. 356 (1886).

8. 403 U.S. 365 (1971). 
In Part III, I offer some preliminary observations on how recognition of the immigrant equality element may affect current assessment of sub-federal laws. I argue that equality adds a ground for preempting laws that cause discrimination and for validating measures that promote immigrant integration and protection. ${ }^{9}$

\section{THE REEMERGENCE OF IMMIGRATION PREEMPTION: ARIZONA $V$. UNITED STATES}

In Arizona v. United States, the Supreme Court struck down three of four contested provisions of SB 1070, Arizona's immigration enforcement law. ${ }^{10}$ The Court's decision articulated a sweeping vision of the federal immigration enforcement power-and the attendant preemption of laws threatening to exceed it or encroach on its priorities. ${ }^{11}$

9. The current controversies over state and city laws have generated substantial scholarship on "immigration federalism." For a small sample of valuable commentary addressing current measures, see, for example, Gabriel J. Chin \& Marc L. Miller, The Unconstitutionality of State Regulation of Immigration Through Criminal Law, 61 DUKE L.J. 251 (2011); Kevin R. Johnson, Immigration and Civil Rights: State and Local Efforts to Regulate Immigration, 46 GA. L. REV. 609 (2012); Hiroshi Motomura, Immigration Outside the Law, 108 COluM. L. REV. 2037 (2008); Cristina M. Rodriguez, The Significance of the Local in Immigration Regulation, 106 MICH. L. REV. 567 (2008); Peter H. Schuck, Taking Immigration Federalism Seriously, 2007 U. CHI. LEGAL F. 57 (2007). An earlier round of scholarship addressed issues arising from California's Proposition 187 adopted in 1994. See, e.g., Stephen H. Legomsky, Immigration, Federalism, and the Welfare State, 42 UCLA L. REV. 1453 (1995); Hiroshi Motomura, Immigration and Alienage, Federalism and Proposition 187, 35 VA. J. INT'L L. 201 (1994); Gerald L. Neuman, Aliens as Outlaws: Government Services, Proposition 187, and the Structure of Equal Protection Doctrine, 42 UCLA L. REV. 1425 (1995); Peter J. Spiro, The States and Immigration in an Era of Demi-Sovereignties, 35 VA. J. INT'L L. 121 (1994). I am not aware of any articles examining the 1870 Civil Rights Act in relation specifically to the Supremacy Clause and immigration preemption.

10. 132 S. Ct. at 2510-11. See Support Our Law Enforcement and Safe Neighborhoods Act, ARIZ. ReV. STAT. ANN. § 11-1051 (West 2013).

11. For my more extensive discussion of Arizona, and its implications for state immigration laws, see Lucas Guttentag, Immigration Preemption and the Limits of State Power: Reflections on Arizona v. United States, 9 STAN. J. C.R. \& C.L. 1 (2013) [hereinafter Guttentag, Immigration Preemption] (discussing the Court's support for federal primacy in the context of immigration enforcement). For insightful commentary on the Court's ruling, see David Martin, Reading Arizona, 98 VA. L. REV. In BRIEF 41 (2012). See generally Jennifer M. Chacón, The Transformation of Immigration Federalism, 21 WM. \& MARY BILL RTS. J. 577 (2012); The Supreme Court-Leading Cases, 126 HARV. L. REV. 327, 327-37 (2012). For a series of immediate comments on the decision by numerous commentators, see Lucas Guttentag, Online Symposium: Strong on Theory While Profiling Ignored, SCOTUSBLOG (June 25, 2012), http:/ /www.scotusblog.com/2012/06/online-symposium-strong-on-theory-while-profiling-ignored/, and related posts. 
Arizona was a facial challenge by the United States to four elements of SB 1070. The contested sections (1) created a state crime largely tracking the federal offense of failing to register as an alien; ${ }^{12}$ (2) criminalized any attempt by an alien within the state to seek unauthorized employment; ${ }^{13}$ (3) allowed state police officers to arrest any person suspected of removability who committed a "public offense"; ${ }^{14}$ and (4) required police to verify the immigration status of anyone stopped for other grounds if that person was suspected of being present in the country unlawfully. ${ }^{15}$ The last provision, Section 2B, dubbed the "show me your papers" law, incited particular criticism from civil rights groups for inviting racial and ethnic profiling and discrimination. $^{16}$

The Court held the first three sections preempted on the grounds that they criminalized conduct Congress had chosen not to punish, imposed penalties that exceeded federal levels, and required Arizona police agencies to arrest and detain individuals whom federal authorities might choose not to pursue. ${ }^{17}$ The Court declined to hold Section $2 \mathrm{~B}$ facially preempted but left open other possible challenges to that provision. ${ }^{18}$

The precise rationale for invalidating each section differed, but the Court generally relied on the federal immigration statute and the federal government's exclusive control and discretion over immigration enforcement decisions. The state crime for failing to register was held preempted by the federal statute's "full set of standards governing alien registration," which had been "designed as a "harmonious whole." 19 Even complementary state legislation was unacceptable because Congress had occupied the field and because Arizona's penalties conflicted with the federal scheme. ${ }^{20}$ The state

12. S.B. $1070 \S 3$, ARIZ. REV. STAt. AnN. § 13-1509.

13. S.B. $1070 \S 5(C)$, ARIZ. ReV. STAt. AnN. § 13-2928.

14. S.B. 1070 § 6, ARIZ. REV. STAT. ANN. \$ 13-3883.

15. S.B. $1070 \S 2$ (B), ARIZ. REV. STAT. ANN. § 11-1051.

16. See, e.g., SB 1070 at the Supreme Court, AM. CIV. LIBERTIES UnION, http://www.aclu. org/whats-stake-sb-1070-supreme-court-0 (last visited Feb. 6, 2013) (characterizing § 2(B) as "the most hotly disputed" part of SB 1070 and noting that it "invite[d] racial profiling"). See also infra note 27.

17. Arizona v. United States, 132 S. Ct. 2492, 2501-07 (2012).

18. Id. at 2510 .

19. Id. at 2502 (quoting Hines v. Davidowitz, 312 U.S. 52, 72 (1941)). See also id. at 2530 (Alito, J., concurring) (finding that federal registration law constitutes "a single integrated and all-embracing system," representing a careful balancing of priorities (citation omitted) (internal quotation marks omitted)).

20. Id. at 2502-03. 
crime for engaging in unauthorized employment was held preempted on the ground that it conflicted with Congress's decision to adopt comprehensive legislation regulating employers and penalizing their hiring of unauthorized immigrant workers-and not to impose criminal sanctions on the workers themselves. ${ }^{21}$

The third measure, which authorized state officers to arrest, without a warrant, any person whom the officer believed to have committed "any public offense" that would render him or her removable, was held preempted in significant part because the power conferred on state officers by SB 1070 exceeded that of federal officers under the INA. ${ }^{22}$ The Court also noted the importance of federal enforcement discretion and pointed out that not all aliens deemed removable are actually placed into removal proceedings. The Court recognized that the federal government's policy of prosecutorial discretion "embraces immediate human concerns" and that enforcement priorities reflect multiple considerations and individual equities. ${ }^{23}$ The Court found a lack of federal authorization for Arizona's arrest law and determined that such unilateral state authority would upend the discretion properly exercised by the federal government, essentially "allow[ing] the state to achieve its own immigration policy." 24 The state statute raised serious concerns that foreign nationals exempted from enforcement under federal

21. Id. at 2504-05. The Arizona decision found federal preemption notwithstanding the general police power of states to regulate employment recognized in DeCanas v. Bica, 424 U.S. 351 (1976), and the Court's prior ruling in Chamber of Commerce v. Whiting, $131 \mathrm{~S}$. Ct. 1968 (2011), which allowed states to revoke the licenses of businesses who knowingly hired undocumented workers based on a close (and disputed) reading of a statutory savings clause in the INA, $i d$. at 1978. The Court distinguished DeCanas on the ground that although Section 5 (C) aligned with the purpose of the Immigration Reform and Control Act (IRCA)sanctioning unauthorized employment-its means of enforcement did not because it criminalized employees and thereby conflicted with Congress's chosen approach. In Whiting, the Court upheld a state law sanctioning businesses that knowingly employed unauthorized aliens. Id. at 1987. The law also mandated the use of E-Verify, an electronic database used to determine employee eligibility to work in the United States, which federal law makes optional. The Court held that the statutory proviso to IRCA's express preemption provision constituted a "savings clause" that authorized Arizona's license-based scheme. Id. The Court further held that the federal statute regulating imposition of E-Verify applied only to the Secretary of DHS and that the state requirement was consistent with the federal purpose. See id at 1986. With regard to both state mandates, the Court looked to the INA and read the immigration statute as permitting - not barring - the state law. Id.

22. Arizona, 132 S. Ct. at 2505-07. See 8 U.S.C.A. § 1357(a) (West 2013) (enumerating the powers conferred on any officer and employee of the state that can be exercised without requiring a warrant).

23. Arizona, 132 S. Ct. at 2499.

24. Id. at 2506 . 
priorities would be "unnecessar[ily] harass[ed]" by local officials. ${ }^{25}$

The Court did not enjoin the Section 2B provision that required state and local police officers to verify the immigration status of anyone they stopped if they possessed "reasonable suspicion" that the person being detained was an unlawfully present alien. ${ }^{26}$ The Court rejected the United States's contention that the provision conflicted with federal immigration law and did not engage with opponents' concern that the law would invite discriminatory policing based on racial profiling. ${ }^{27}$ The Court found that SB 1070 did not necessarily conflict with federal law because state officials are authorized to communicate with the federal government about the immigration status of detained individuals. ${ }^{28}$ Section $2 \mathrm{~B}$ did not interfere with prosecutorial discretion because Arizona law did not compel the federal government to take action against someone apprehended by state authorities. $^{29}$

$$
* * *
$$

Arizona's analytical approach involved a methodical, provisionby-provision reading of SB 1070 and the federal law governing immigration regulation and control. The Court outlined congressional intent in the federal immigration statute, the extent to which enforcement control was expressly or impliedly reserved to the federal government, the potential or actual conflict between federal primacy and state authority, and the foreign affairs source for federal immigration authority. The analysis turned on the breadth and complexity of the federal legislative and regulatory framework, the careful balance struck between federal priorities and objectives within this framework, and the importance of discretion in immigration

25. Id. (noting that allowing state arrest "without any input from the Federal Government about whether an arrest is warranted ... would allow the State to achieve its own immigration policy [and $t$ ] he result could be unnecessary harassment of some aliens . . . whom federal officials determine should not be removed").

26. Id. at 2507-10.

27. See Brief for Leadership Conference on Civil and Human Rights et al. at 12, Arizona, 132 S. Ct. 2492 (No. 11-182) (noting that "[c]itizens of color will disproportionately bear the burden of 'papers please' policing" and that "racial and ethnic perceptions w[ould] spawn the reasonable suspicion that Section 2 (B) requires").

28. Arizona, $132 \mathrm{~S}$. Ct. at 2508.

29. Id. at 2509 . The Court further noted that "[d]etaining individuals solely to verify their immigration status would raise constitutional concerns." Id. As I have noted elsewhere, the Court imposed important limits on Section 2B's operation and explicitly noted that its ruling "d[id] not mean to 'foreclose other preemption and constitutional challenges to the law as interpreted and applied after it goes into effect." Guttentag, Immigration Preemption, supra note 11, at 13-15 (quoting Arizona, 132 S. Ct. at 2510). 
enforcement. Sprinkled throughout the Arizona opinion are references to the "extensive,", "comprehensive," federal power over immigration.

Though the Court volubly discussed the immigration power and its attendant preemptive force, it defined the federal interest principally by dissecting the federal immigration laws governing admission, expulsion, enforcement, discretion, and control, i.e., what I refer to as the immigration control aspect of federal law. Notably absent from the Court's analysis was SB 1070's potential to incite discrimination and consideration by the Court of an immigrant equality component of federal law. In fact, SB 1070's potentially discriminatory effects were affirmatively discounted at oral argument. ${ }^{33}$

Arizona did not address the prohibition on state "alienage" discrimination in the Civil Rights Act of 1870 as a separate source for immigration preemption. The closest the Court came to acknowledging the relevance of the Arizona law's potential consequences for immigrants themselves arose in the context of the Court's concern that the state law could lead to harassment of foreign nationals by local authorities. ${ }^{34}$ That in turn could impinge on American foreign relations and thereby interfere with the federal government's authority over foreign affairs. ${ }^{35}$

This aspect of the Court's ruling is significant but incomplete. The recognition that harassment of immigrants is an important factor to consider means that preemption depends on more than a granular examination of the INA and that there are federal values at stake beyond those embedded in the immigration statutes. However, the Court's concern with potential harassment remained focused on preserving the federal government's own interests and prerogatives. The fear of harassment of foreigners arose because it might affect the nation's foreign relations, not because foreign nationals themselves

30. Arizona, 132 S. Ct. at 2499.

31. Id. at 2502 .

32. Id. at 2510 .

33. At oral argument, the Chief Justice sought to cabin off any discussion of discrimination-based arguments against SB 1070. At the beginning of his argument, Solicitor General Verrilli was immediately asked: "No part of your argument has to do with racial or ethnic profiling, does it?" and, "So this is not a case about ethnic profiling." Transcript of Oral Argument at 34, Arizona, 132 S. Ct. 2492 (No. 11-182) [hereinafter Arizona Oral Argument].

34. See Arizona, 132 S. Ct. at 2506.

35. Id. 
are protected against local discrimination as a matter of overriding federal law. The Court's approach omits an important aspect of its own preemption jurisprudence that recognizes the deeper claim to immigrant equality stemming from the Civil Rights Act of 1870.

\section{ALIENS, CIVIL RIGHTS, AND RECONSTRUCTION}

For nearly a century after adoption of the Civil Rights Act of 1870, the Supreme Court recognized the principle of immigrant equality as part of the federal framework that preempted state or local laws denying rights, protections, and benefits to non-citizens. The 1870 Act, passed by the Reconstruction Congress, contained express and enduring provisions to protect foreign nationals_-"aliens"-against discrimination. ${ }^{36}$ These protections form a central part of federal policy regarding immigrants and immigration that should be taken into account in contemporary Supremacy Clause analysis. Beginning with Yick Wo v. Hopkins in 1886 and continuing for nearly ninety years through its landmark decision in Graham v. Richardson in 1971, the Supreme Court recognized the equality principle embodied in the Civil Rights Act of 1870 for its contribution to the preemption of state and local immigration measures. ${ }^{37}$ As the Supremacy Clause now reemerges after a lengthy hiatus to serve as a critical limit on state immigration authority, restoring the significance of the 1870 Act in the federal immigration framework is essential.

The key provision of the 1870 Act provides in relevant part that "all persons" shall have the same right as "white citizens" in "every State and Territory" to certain enumerated rights. ${ }^{38}$ That law is now codified at 42 U.S.C. $§ 1981$. It is part of the larger federal framework adopted by Congress in 1870 specifically intended to protect non-citizens against sub-federal discrimination. At that time, Congress's focus was particularly on the treatment of Chinese immigrants in California, but the Act applied broadly to all noncitizens. Over the years, the Supreme Court invoked the protections of the 1870 Act in preempting discriminatory state and local welfare, business, and registration laws that targeted immigrants. The

36. Civil Rights Act of 1870, ch. 114, §§ 16-17, 16 Stat. 140, 144 (codified in part at 42 U.S.C. $\$ 1981$ (2006)). I use the term "alien" throughout this Article to reflect the usage in the case law and the text of the 1870 Act.

37. See generally Graham v. Richardson, 403 U.S. 365 (1971); Yick Wo v. Hopkins, 118 U.S. 356 (1886).

38. Civil Rights Act of $1870 \S 16$. 
prohibition against discrimination featured prominently in key immigration preemption cases across many decades. The Court understood the mandate of non-discrimination as part of the broader national policy governing the treatment and rights of non-citizens in the United States. This Part first recounts the evolution of the 1870 Act and traces the alien anti-discrimination provisions from their origins through their current codification. I then review the Supreme Court's recognition of the alienage provisions in the 1870 Act as an important component of the federal framework preempting state and local immigration laws.

\section{A. The Civil Rights Act of 1870 and the Protection of Aliens}

The origins of the alien-protection sections of the Civil Rights Act of 1870 confirm the Act's intent to limit state discrimination against foreign nationals. The law's subsequent codification helps explain why these protections may today be overlooked in defining the federal scheme that sets limits on state and local authority.

Reconstruction and the civil rights statutes of that era are, of course, the subject of vast scholarship. ${ }^{39}$ But, the fact that this historic civil rights legislation also contained important provisions prohibiting alienage discrimination and protecting immigrants has not been as widely explained. The origins and evolution of the law's alienprotecting elements are not fully set forth in the Supreme Court's cases. ${ }^{40}$ Some scholars have told important aspects of the story as it

39. E.g., David W. Blight, Race and Reunion (2002); Peter CAmejo, Racism, REVOLUTION, REACTION, 1861-1877: THE RISE AND FALl OF RADICAL RECONSTRUCTION (1976); ERIC FONER, RECONSTRUCTION: AMERICA'S UNFINISHED REVOLUTION, 1863-1877 (2002); EARl M. MAltz, THE Fourteenth AMENDMENT AND THE LAW OF THE CONSTITUtion (2003); GEORGE Rutherglen, Civil Rights IN THE SHAdow OF SLAVERY: The Constitution, COMmOn LAW, AND THE Civil Rights ACT OF 1866 (2012); KenNeth M. STAMPP, THE ERA OF RECONSTRUCTION (1965). These works do not focus on the alienage discrimination prohibitions of the 1870 Act or on the development of the Act's particular immigrant-related provisions.

40. I am not aware of any case in which the Court has traced in detail all of the provisions in the 1870 Act protecting aliens against discrimination. The Court has examined the origins of one key part, Section 16 (now codified at 42 U.S.C. $§ 1981$ ), in relation to race discrimination claims in various cases. See, e.g., CBOCS W., Inc. v. Humphries, 553 U.S. 442, 457 (2008) (holding that $\S 1981$ as amended applies to retaliation claims); Gen. Bldg. Contractors Ass'n v. Pennsylvania, 458 U.S. 375, 391 (1982) (holding that $\S 1981$ only prohibits intentional discrimination); McDonald v. Santa Fe Trail Transp. Co., 427 U.S. 273, 287 (1976) (holding that $\S 1981$ reaches private discrimination against white persons); Runyon v. McCrary, 427 U.S. 160, 172 (1976) (holding that $\S 1981$ applies to discriminatory admission practices of private schools); Hurd v. Hodge, 334 U.S. 24, 34 (1948) (holding that Section 16 prohibits enforcement of restrictive racial covenants); Buchanan v. Warley, 245 U.S. 60, 77-79 (1917) (holding that Section 16 contravened a racially discriminatory municipal ordinance). With the exception of 
relates to discrimination against Chinese immigrants, ${ }^{41}$ but their work does not examine the centrality of the 1870 Act in the particular context of immigration federalism and federal preemption of state alienage laws. ${ }^{42}$ Revisiting the origins, text, and codification of the Civil Rights Act of 1870 helps illuminate the Act as an important source for understanding federal policies and interests regarding immigrants and immigration.

\section{Enactment During Reconstruction}

\section{a. The Civil Rights Act of 1866}

Exploring the federal prohibitions against state alienage discrimination begins with the Civil Rights Acts of 1866. The 1866 Act, which itself addressed only race and citizenship, is the essential starting point because it enacted a template that became the model for addressing alienage discrimination a few years later.

The Thirty-Ninth Congress adopted the Civil Rights Act of 1866 (in April 1866 over President Johnson's veto) ${ }^{43}$ to enforce the rights of newly freed slaves under the recently-ratified Thirteenth Amendment. ${ }^{44}$ The Fourteenth Amendment was considered by the

the cases I discuss in the text, the Court has addressed the 1870 Act's application to alienage discrimination only indirectly. See, e.g., Runyon, 427 U.S. at 193-204 (White, J., dissenting) (noting, in consideration of the legislative history, that "one of the classes of persons for whose benefit the statute was intended was aliens"); United States v. Classic, 313 U.S. 299,327 n.10 (1941) (explaining, in discussing another section, that the claimed purpose "was to extend [the Civil Rights Act's] benefits to aliens").

41. See Charles J. McClain, In Search of Equality: The Chinese Struggle AgAinst DisCRIMINATION IN NINETEENTH-CENTURY AMERICA (1994); Charles McClain, Jr., The Chinese Struggle for Civil Rights in Nineteenth Century America: The First Phase, 1850-1870, 72 CALIF. L. REV. 529 (1984). See also Stephen Knight, The First Time as Tragedy, The Second Time as Farce: Proposition 187, Section 1981 and the Rights of Aliens, 15 UCLA PAC. BASIN L.J. 289 (1997). See generally GEORGE RUTHERGLEN, CIVIL RIGHTS IN THE SHADOW OF SLAVERY: The Constitution, COMmOn LAW, AND THE Civil Rights ACT OF 1866 80-83 (2013).

42. My analysis considers the existing historical sources and scholarship to examine the importance of the 1870 Act in relation to the contemporary debate over immigration federalism and preemption. I do not undertake an independent examination of the history of the alienage provisions in the 1870 Act or the motivations of its proponents. For now, my purpose is simply to show the significance of the alien-protection provisions specifically to preemption. My initial thoughts appear in Guttentag, Discrimination, supra note *. The existing literature on the 1870 Act's prohibition against alienage discrimination focuses on 42 U.S.C. $\$ 1981$ without considering its relevance to federal preemption. See, e.g., Aaron Danzinger, The Scope of 42 U.S.C. § 1981: Protection Against Private Alien Age Discrimination, 11 Geo. ImMIG. L.J. 527 (1997); Angela M. Ford, Private Alienage Discrimination and the Reconstruction Amendments: The Constitutionality of 42 U.S.C. $\$ 1981$, 49 U. KAN. L. REV. 457 (2001); Knight, supra note 41.

43. Civil Rights Act of 1866, ch. 31, 14 Stat. 27, 29.

44. See Cong Globe, 39th Cong., 1st Sess. 474 (1866) (statement of Sen. Trumbull). 
same Congress and approved for submission to the states that June, but it was not ratified until July $1868 .^{45}$

The key parts of the 1866 Act for present purposes are the second clause of Section 1 and the entirety of Section 2. In Section 1, Congress first ensured citizenship for all persons born in the United States. $^{46}$ The second clause of Section 1 then mandated equality between white and non-white citizens with respect to a range of civil and economic rights enumerated in the statute. ${ }^{47}$ It required that "all ... citizens" be treated the same as "white citizens" in designated respects. Section 2 then further addressed racial discrimination by imposing criminal penalties for deprivation of rights or disparate punishments based on race or prior condition of slavery or involuntary servitude. ${ }^{48}$ That provision imposed a fine and

45. See Cong. Globe, 39th Cong., 1st Sess. 3148-49 (1866); Proclamation No. 13, 15 Stat. 708, 711 (July 28, 1868). As scholars and the Court have long noted, the 1866 Act and the Fourteenth Amendment are closely intertwined. See Hurd v. Hodge, 334 U.S. 24, 31-33 (1948) (showing how the 1866 Act and the Fourteenth Amendment "were closely related both in inception and in the objectives which Congress sought to achieve"); HORACE EDGAR FLACK, THE AdOPTION OF THE FOURTEENTH AMENDMENT 94-97 (photo. reprint 1965) (1908) (arguing that a primary reason for the adoption of the Fourteenth Amendment was to set the 1866 Act on more solid constitutional footing).

46. The first clause of Section 1 addressed citizenship in language very similar to that in the later Fourteenth Amendment. Compare Civil Rights Act of $1866 \S 1$, cl. 1 ("Be it enacted by the Senate and House of Representatives of the United States of America in Congress assembled, That all persons born in the United States and not subject to any foreign power, excluding Indians, not taxed, are hereby declared to be citizens of the United States."), with U.S. CONST. amend. XIV, § 1, cl. 1 ("All persons born or naturalized in the United States, and subject to the jurisdiction thereof, are citizens of the United States and of the State wherein they reside."). See generally GARRETT EPPS, DEMOCRACY REBORN: THE FOURTEENTH AMENDMENT AND THE FIGHT FOR EQUAL RIGHTS IN POST-CIVIL WAR AMERICA (2006) (describing the "battle" over the Fourteenth Amendment and how the Amendment changed the country).

47. Civil Rights Act of $1866 \S 1$, cl. 2. The first clause of Section 1 provided:

[A]nd such citizens, of every race and color, without regard to any previous condition of slavery or involuntary servitude, except as a punishment for crime whereof the party shall have been duly convicted, shall have the same right, in every State and Territory in the United States, to make and enforce contracts, to sue, be parties, and give evidence, to inherit, purchase, lease, sell, hold, and convey real and personal property, and to full and equal benefit of all laws and proceedings for the security of person and property, as is enjoyed by white citizens, and shall be subject to like punishment, pains, and penalties, and to none other, any law, statute, ordinance, regulation, or custom, to the contrary notwithstanding.

Id. at cl. 1 .

48. Id. $\S 2$. The full text of Section 2 of the 1866 Act read:

And be it further enacted, That any person who, under color of any law, statute, ordinance, regulation, or custom, shall subject, or cause to be subjected, any inhabitant of any State or Territory to the deprivation of any right secured or protected by this act, or to different punishment, pains, or penalties on account of such person having at any time been held in a condition of slavery or involuntary servitude, except as a punishment for crime whereof the party shall have been duly convicted, or 
imprisonment (up to a year) on any person who, under color of law or custom, deprived any inhabitant of enumerated rights or imposed "punishments, pains or penalties" different than on a "white person[]" because of a person's former slave status or "by reason of his color or race." 49

\section{b. The 1870 Act}

In May 1870, Congress enacted further civil rights legislation. The Voting Rights Enforcement Act, commonly referred to as the Enforcement Act of 1870 or the Civil Rights Act of $1870,^{50}$ was adopted after the Fourteenth and Fifteenth Amendments had come into force (in July 1868 and February 1870, respectively). ${ }^{51}$ The 1870 Act, although largely focused on voting rights, contained three distinct substantive provisions aimed at discrimination against non-citizens. The key protections appeared in Sections 16 and 17. These were modified versions of Sections 1 and 2 of the recently-adopted 1866 Act. But the new statutes were expanded to encompass discrimination against non-citizens, i.e., "alienage" discrimination.

The "Alien" Provisions-Sections 16 and 17. Sections 16 and 17 of the 1870 Act enacted a broad measure of equality between citizens and aliens in "every State and Territory." 52 These provisions (along with what became Section 18) originated in a separate bill, S.365, introduced in 1870 by Senator William Morris Stewart of Nevada.

by reason of his color or race, than is prescribed for the punishment of white persons, shall be deemed guilty of a misdemeanor, and, on conviction, shall be punished by fine not exceeding one thousand dollars, or imprisonment not exceeding one year, or both, in the discretion of the court.

Id.

49. Id. The remaining sections of the 1866 Act enforced its principal provisions but did not directly bear on later developments protecting non-citizens. Sections 3 through 10 addressed enforcement and jurisdictional issues. Section 3 conferred exclusive jurisdiction on the federal courts; Section 4 gave enforcement powers to United States attorneys and marshals; Section 5 imposed certain duties on those officers to execute warrants; Section 6 made it a crime to interfere with the officers' duties; Section 7 provided payment to the officers; Section 8 allowed the President to assign officers to locations where they were needed; Section 9 authorized the President to deploy military forces to enforce the Act; and Section 10 provided for Supreme Court review. Id. $\$ \S 3-10$.

50. Civil Rights Act of 1870, ch. 114, 16 Stat. 140 ("An Act to enforce the Right of Citizens of the United States to vote in the several States of this Union, and for other Purposes.").

51. FLACK, supra note 45, at 223-24.

52. Civil Rights Act of $1870 \S \S 16-17$.

53. See CONG. Globe, 41st Cong., 2d Sess. 323 (1870) (introducing S.365). Justice White refers to S.365 in his Runyon dissent, but focuses on what became Section 16 of the 1870 Act. See Runyon v. McCrary, 427 U.S. 160, 195-201 (1976) (White, J., dissenting) (citing S.365 in 
Stewart's stated purpose for S.365 was to extend the protections of the Civil Rights Act of 1866 to aliens: "The original [1866] civil rights bill protected all persons born in the United States in the equal protection of the laws. This bill extends it to aliens, so that all persons who are in the United States shall have the equal protection of our laws." 54 Stewart's original bill had three sections, which were subsequently inserted virtually verbatim into the bill that became the Civil Rights Act of $1870 .^{55}$ Stewart was particularly concerned with addressing the discrimination and abuse visited upon Chinese nationals in California and the West: "If the State courts do not give them the equal protection of the law, if public sentiment is so inhuman as to rob them of their ordinary civil rights, . . . I would be

noting the origins of 42 U.S.C. $§ 1981)$.

54. Cong. Globe, 41st Cong., 2d Sess. 1536 (1870) (statement of Sen. Stewart).

55. See id. (recording the text of the Stewart Bill). The entirety of S.365 provided:

Be it enacted, \&c., That all persons within the jurisdiction of the United States, Indians not taxed excepted, shall have the same right in every State and Territory in the United States to make and enforce contracts, to sue, be parties, give evidence, and to the full and equal benefit of all laws and proceedings for the security of person and property as is enjoyed by white citizens, and shall be subject to like punishments, pains, penalties, taxes, licenses, and exactions of every kind and none other, any law, statute, ordinance, regulation, or custom to the contrary notwithstanding. No tax or charge shall be imposed or enforced by any State upon any person emigrating thereto from a foreign country which is not equally imposed and enforced upon every person emigrating to such State from any other foreign country, and any law of any State in conflict with this provision is hereby declared null and void.

Sec. 2. And be it further enacted, That any person who, under color of any law, statute, ordinance, regulation, or custom shall subject, or cause to be subjected, any inhabitant of any State or Territory to the deprivation of any right secured or protected by this act, or to different punishment, pains, or penalties on account of such person being an alien, or by reason of his color or race, than is prescribed for the punishment of white persons, shall be deemed guilty of a misdemeanor, and, on conviction, shall be punished by fine not exceeding $\$ 1,000$ or imprisonment not exceeding one year, or both, in the discretion of the court.

Sec. 3. And be it further enacted, That the act to protect all persons in the United States in their civil rights and furnish the means of their vindication, passed April 9, 1866 , is hereby reenacted, and said act, except the first and second sections thereof, is hereby referred to and made a part of this act.

Id. S.365 had been progressing separately since January 10, 1870 until Senator Stewart proposed it as an amendment to the voting rights bill in May of 1870. See CONG. GLOBE, 41st Cong., 2d Sess. 323 (1870) (introducing S.365). See also CoNG. GlobE, 41st Cong., 2d Sess. 3480 (1870) (showing the movement to amend the voting rights bill to add S.365). Between Stewart's introduction and passage of the 1870 Act, a few modest changes in the language of the provisions occurred. The original S.365 introduced by Senator Stewart excluded "Indians not taxed" from the protections of Section 1, but that stipulation was omitted when S.365 was made a part of the 1870 Act. Compare Cong. Globe, 41st Cong., 2d Sess. 1536 (1870), with Civil Rights Act of $1870 \S 16$. The criminal provision forbidding differential punishment for aliens and "white persons" was modified to forbid differential punishment for aliens and "citizens." Compare Cong. GlobE, 41st Cong., 2d Sess. 1536 (1870), with Civil Rights Act of $1870 \S 17$. 
less than a man if I did not insist ... that that provision shall go on this bill." $" 56$

The two alienage provisions of the 1870 Act provided as follows:

[Section 16:] [A]ll persons within the jurisdiction of the United States shall have the same right in every State and Territory in the United States to make and enforce contracts, to sue, be parties, give evidence, and to the full and equal benefit of all laws and proceedings for the security of person and property as is enjoyed by white citizens, and shall be subject to like punishment, pains, penalties, taxes, licenses, and exactions of every kind, and none other, any law, statute, ordinance, regulation, or custom to the contrary notwithstanding. No tax or charge shall be imposed or enforced by any State upon any person immigrating thereto from a foreign country which is not equally imposed and enforced upon every person immigrating to such State from any other foreign country; and any law of any State in conflict with this provision is hereby declared null and void. ${ }^{57}$

[Section 17:] And be it further enacted, That any person who, under color of any law, statute, ordinance, regulation, or custom, shall subject, or cause to be subjected, any inhabitant of any State or Territory to the deprivation of any right secured or protected by the last preceding section of this act, or to different punishment, pains, or penalties on account of such person being an alien, or by reason of his color or race, than is prescribed for the punishment of citizens, shall be deemed guilty of a misdemeanor, and, on conviction, shall be punished by fine not exceeding one thousand dollars, or imprisonment not exceeding one year, or both, in the

56. Cong. Globe, 41st Cong., 2d Sess. 3658 (1870) (statement of Sen. Stewart). See also $i d$. at 3807 (statement of Sen. Stewart) ("I congratulate the country, particularly [for] those provisions which extend the strong arm of the Government to the protection of the Chinese; those provisions which protect those industrious, helpless people whom we have invited to our shores ...."). The story of Senator Stewart, his goal of addressing discrimination against Chinese immigrants in California, the evolution of S.365, its inclusion in the Voting Rights Act, and the role of the San Francisco Chinese community in pursuing this legislation are recounted in fascinating detail by Charles McClain. MCCLAIN, supra note 41. See generally LUCY E. SALYER, LAWS HARSH As TIGERS: CHINESE IMMIGRANTS AND THE SHAPING OF MODERN IMMIGRATION LAW (1995). To acknowledge Stewart's role in sponsoring these protections is not to express a view on his motivation. McClain recognizes a confluence of interests between the Chinese who sought to protect themselves against discrimination and the "Caucasian business community" that viewed them as a source of labor. McClain, Jr., supra note 41, at 534 n.22 (1984) ("Some evidence suggests that Chinese community leaders saw some, though by no means all, leaders of the Caucasian business community as natural allies and worked with them when that appeared to inure to their own benefit.").

57. Civil Rights Act of $1870 \S 16$. 
discretion of the court. ${ }^{58}$

First Sentence of Section 16. The first sentence of Section 16 is the most well-known of the Act's provisions. Today it is codified at 42 U.S.C. $\$ 1981$. The language of Section 16 was patterned directly on Section 1 of the 1866 Act with a critical difference. The new Section 16 provided that "all persons" (instead of only "citizens") be treated the same as "white citizens." It thereby went significantly beyond prohibiting discrimination between white and non-white citizens. By requiring equality between persons and citizens, Section 16 prohibited discrimination on the basis of citizenship, or as it came to be called, on the basis of alienage.

Section 16 differed in two other notable respects from the earlier 1866 Act with regard to the particular areas of non-discrimination listed in the statute. Section 16 added "taxes, licenses and exactions" to the list of activities for which discrimination was barred, and the law omitted the right "to inherit, purchase, lease, sell, hold and convey real and personal property" from its coverage. ${ }^{60}$ In short, the effect of Section 16 was to prohibit discrimination both on the basis of alienage (persons versus white citizens) and on the basis of race (persons versus white citizens) as to the lengthy list of civil and economic rights specified in the law, but with the important exception of property rights.

Discrimination with regard to property rights continued to be prohibited by the earlier Section 1 from the 1866 Act. But that section governed property discrimination only for citizens and only with respect to race. ${ }^{61}$ Alienage discrimination was not encompassed by the

58. Id. $\$ 17$.

59. Id. $\S 16$.

60. Compare id. $\S 16$ (encompassing the right "to make and enforce contracts, to sue, be parties, give evidence, and to the full and equal benefit of all laws and proceedings for the security of person and property as is enjoyed by white citizens," and also mandating that persons within the jurisdiction of the United States "be subject to like punishment, pains, penalties, taxes, licenses, and exactions of every kind, and none other" (emphasis added)), with Civil Rights Act of 1866, ch. 31, § 1, cl. 2, 14 Stat. 27, 27 (encompassing the right "to make and enforce contracts, to sue, be parties, and give evidence, to inherit, purchase, lease, sell, hold, and convey real and personal property, and to full and equal benefit of all laws and proceedings for the security of person and property, as is enjoyed by white citizens," and also mandating that all citizens "be subject to like punishment, pains, and penalties, and to none other" (emphasis added)). See also Cong. GlobE, 41st Cong., 2d Sess. 1536 (1870) (statement of Sen. Stewart) ("If the Senator will examine this bill in connection with the original civil rights bill, he will see that it has no reference to inheriting or holding real estate.").

61. See supra note 47 and accompanying text. 
earlier law, and hence aliens were not entitled to equality as to property rights under the statute. ${ }^{62}$

Second Sentence of Section 16. The second sentence of Section 16 was also directly addressed at discriminatory practices affecting noncitizens-but with the particular aim of preventing state discrimination among different immigrant groups. The provision prohibited any state from imposing or enforcing any tax or charge on any person immigrating to the state from a foreign country if that tax was not "equally imposed" on every person immigrating "from any other foreign country."

Section 17. Section 17 of the 1870 Act imposed criminal penalties for alienage discrimination by enacting language that closely tracked but significantly expanded the criminal prohibitions originally enacted by Section 2 of the 1866 Act. The 1866 Act had criminalized the differential imposition of "punishment, pains, or penalties" based on "color or race" or prior slavery. ${ }^{64}$ The new law explicitly expanded the scope of the prohibition by also outlawing differential treatment "on account of such person being an alien." 65

In addition, Section 17 changed the category of persons whose treatment set the equality baseline to which others were entitled. The 1866 Act provided that others be treated the same as "white persons." ${ }^{66}$ Section 17 instead required that everyone be treated

62. The omission regarding property equality under the Civil Rights Act of 1870 may help to explain the subsequent general acceptance of state laws discriminating against non-citizens in land inheritance and ownership in the era before Graham v. Richardson, 403 U.S. 365, 366-68 (1971). See infra note 106 (discussing property discrimination cases).

63. See supra text accompanying note 57. This provision has been largely forgotten as it was repealed in 1952. See Immigration and Nationality Act, Pub. L. No. 82-414, § 403(a)(1), 66 Stat. 163, 279 (1952) (repealing the tax provision of Section 16).

64. Civil Rights Act of $1866 \S 2$.

65. Civil Rights Act of $1870 \S 17$ (emphasis added). See supra text accompanying note 58 . The Supreme Court has read this section as authorizing punishment of anyone for either "willfully subjecting any inhabitant to the deprivation of rights secured by the Constitution" or for "willfully subjecting any inhabitant to different punishments on account of his color or race [or alienage] than are prescribed for the punishment of citizens." United States v. Classic, 313 U.S. 299, 327 (1941).

66. Both Section 2 (from 1866) and Section 17 (from 1870) referred to every "inhabitant" of any "State or Territory" being protected against deprivation of rights on account of any such "person" being an alien or by reason of his color. Compare Civil Rights Act of $1866 \S 2$, with Civil Rights Act of $1870 \S 17$. I am not aware of any congressional discussion of the reason for using the term "inhabitant." The term also appears in the earlier laws restricting immigration from China (and later extended) presumably to broaden the scope of the restriction. See infra note 78 . As noted below, these terms were changed in the 1875 codification and again in 1994 by 
equally with "citizens." The statute thus juxtaposed all persons (or inhabitants) with citizens thereby underscoring that discriminatory treatment of non-citizens was impermissible. ${ }^{67}$

Section 18. Section 18 reenacted the entire Civil Rights Act of 1866 and specified that Sections 16 and 17 (the alienage provisions) "be enforced pursuant to the provisions of said act."

In sum, the 1870 Act enumerated specified rights and commanded equality between citizens and non-citizens, outlawed differential entry taxes based on nationality or country of origin, and imposed criminal penalties for subjecting a person to discriminatory punishment "on account of . . . being an alien." Congress expressly barred discrimination between citizens and aliens using the same categorical language that it had initially deployed to condemn discrimination based on race or color in the 1866 Act. The Civil Rights Act of 1870 thus enacted an emphatic federal prohibition against alienage discrimination by states in critical areas of public life.

\section{The Subsequent Codification}

Between the adoption of the Act in 1870 and today's codification of its provisions, the protections for non-citizens that Congress enacted have appeared in different titles and chapters of the federal code. This process, and the disaggregation of the 1870 Act into separate statutes, has somewhat obscured the Act's importance to immigration discrimination and its relevance to federal preemption. ${ }^{69}$

congressional amendment. See infra notes 81 and 84 and accompanying text.

67. Compare Civil Rights Act of 1866 § 2, with Civil Rights Act of 1870 § 17. Section 17 also omitted the earlier reference to previous condition of slavery (perhaps because that was assumed to be encompassed in the race and color protection).

68. Civil Rights Act of $1870 \S 18$. Section 18 reads in its entirety:

And be it further enacted, That the act to protect all persons in the United States in their civil rights, and furnish the means of their vindication, passed April nine, eighteen hundred and sixty-six, is hereby re-enacted; and sections sixteen and seventeen hereof shall be enforced according to the provisions of said act.

Id. Scholars assume that the reenactment was intended to ensure that the 1866 Act was grounded in the Fourteenth Amendment as well as the Thirteenth to address concerns about the earlier law's constitutionality. See FLACK, supra note 45, at 224; George Rutherglen, The Improbable History of Section 1981: Clio Still Bemused and Confused, 55 SUP. CT. REV. 303, 313 (2003); Danielle Tarantolo, Note, From Employment to Contract: Section 1981 and Antidiscrimination for the Independent Contractor Workforce, 116 YALE L.J. 170, 188 (2006). No rationale is presented in the debates, however. See FLACK, supra note 45, at 224 ("[I]t is strange that no reference was made as to this purpose."). The Thirteenth Amendment foundation for Section 16 supported its application to private discrimination. See infra notes 72 and 172.

69. A schematic flow chart depicting the origins and codifications appears infra at pp. 26. 


\section{a. 1875 Revised Statutes}

Soon after the 1870 Act, a codification of federal law occurred. The Revised Statutes of $1875^{70}$ synthesized and consolidated the federal laws enacted by Congress into a comprehensive collection for the first time. ${ }^{71}$ This has particular relevance because elements of Sections 1 and 2 of the 1866 Act and of Sections 16 and 17 of the 1870 Act were combined in the codification process. $^{72}$ After this 1875 codification, the location of the different statutes changed over the years, but the operative language of the key provisions (relating to the aspects at issue here) remained largely unaltered, with a few exceptions that are detailed below.

In the 1875 codification, the overlapping prohibitions enacted in Section 1 of the 1866 Act and reenacted more expansively by the first sentence of Section 16 of the 1870 Act were codified in the "Civil Rights" title of the Revised Statutes. ${ }^{73}$ The core requirement of equality between "persons" and "white citizens" (with regard to enumerated rights) established by Section 16 became Revised Statutes Section $1977 .^{74}$ That language has remained intact ever since. ${ }^{75}$

70. This codification is often referred to as the "Revised Statutes of 1874." I have chosen to use "Revised Statutes of 1875 " following the date of publication (rather than enactment) of the original edition. See Hamilton Fish, Certification of THE REVISED STATUTES OF THE UNITED STATES (1st ed. 1875). This comports with the naming system of the Library of Congress, Federal Statutes: Subject Arrangement of Statutes, LIBRARY OF CONGRESS, www.loc.gov/law/help/statutes.php (last visited Mar. 2, 2013), as well as some other publications, e.g., MCCLAIN, supra note 41, at 68 (1996); DAVID SCHULTZ, ENCYCLOPEDIA OF AMERICAN LAW 443 (2009); Richard STEVEN STREET, BEASTS OF THE FiELD: A NARRATIVE History OF CALIFORNIA FARM WORKERS, 1769-1913 349 (2004).

71. See Roy G. Fitzgerald, Preface to THE CODE OF THE LAWS OF THE UNITED STATES OF AMERICA (1926).

72. This has engendered controversy over the constitutional foundations of the provisions and the intentional or inadvertent consequences of the codification process. There is disagreement over whether $\S 1981$ was grounded in the 1866 Act to enforce the Thirteenth Amendment - thereby reaching private conduct-or only in the 1870 Act pursuant to the Fourteenth Amendment, and thereby limited to state action. Compare Runyon v. McCrary, 427 U.S. 160, 179 (1976) (stating that $\S 1981$ "constitutes an exercise of federal legislative power under Section 2 of the Thirteenth Amendment"), with Runyon, 427 U.S. at 205-07 (White, J., dissenting) (concluding that $\S 1981$ derives only from the 1870 Act and the Fourteenth Amendment). That disagreement has been superseded by the amendments enacted by the Civil Rights Act of 1991 and, in any case, does not matter for the essential point here: that Congress intended to protect aliens, at a minimum, against discriminatory state laws. See infra note 172.

73. Revised Statutes, tit. 24, $\S \S 1977-78,18$ Stat. 1, 348 (1874).

74. Id. $\$ 1977$.

75. See 42 U.S.C.A. $§ 1981$ (West 2013) (using the same language as Section 1977). Section 1977 of the Revised Statutes provided:

All persons within the jurisdiction of the United States shall have the same right in every State and Territory to make and enforce contracts, to sue, be parties, give evidence, and to the full and equal benefit of all laws and proceedings for the security 
The requirement of racial equality for all citizens with regard to property rights appeared only in Section 1 of the 1866 Act. It was culled from the 1866 Act language and separately codified in Section 1978 , immediately adjacent to the codification of Section $16 .^{76}$

The second sentence of Section 16 (from 1870), which prohibited discrimination among aliens in state landing taxes based on country of origin, was codified in an entirely different location under the "Immigration" title at Section 2164. ${ }^{77}$ It appeared alongside provisions of the so-called "Anti-Coolie Act," which restricted the entry of certain Chinese, Japanese, and other Asian immigrants into the United States. ${ }^{78}$ This underscores the broader point that federal law simultaneously authorized federal classifications while outlawing state discrimination on the same or similar grounds.

The third prohibition in the 1870 Act-Section 17's criminalizing of discrimination against persons on account of race, color, or "being an alien"-was combined with other enactments and codified at Section 5510 as part of the "Crimes" title. ${ }^{79}$ Although Section 5510

of persons and property as is enjoyed by white citizens, and shall be subject to like punishment, pains, penalties, taxes, licenses, and exactions of every kind, and to no other.

Revised Statutes $\S 1977$. Later amendments added provisions to the statute but did not alter this text.

76. Revised Statutes $§ 1978$. Section 1978 provided: “All citizens of the United States shall have the same right, in every State and Territory, as is enjoyed by white citizens thereof to inherit, purchase, lease, sell, hold, and convey real and personal property." Id. Today that provision is codified at 42 U.S.C. $\S 1982$.

77. See id. $\S 2164$ (codifying the second sentence of Section 16). Section 2164 provided: "No tax or charge shall be imposed or enforced by any State upon any person immigrating thereto from a foreign country, which is not equally imposed and enforced upon every person immigrating to such State from any other foreign country." Id.

78. See id. $\S \S 2158-63$ (showing sections derived from An Act to prohibit the 'Coolie Trade' by American Citizens in American Vessels, ch. 27, 12 Stat. 340 (1862)). The 1862 "AntiCoolie" Act initially applied only to "inhabitants or subjects of China." An Act to prohibit the 'Coolie Trade' § 1. It was amended in 1869 to extend to "Japan or any other oriental country." Act of Feb. 9, 1869, ch. 24, 15 Stat. 269 (1869). See generally infra note 187.

79. See Revised Statutes $\S 5510$. The marginalia to Section 5510 in the Revised Statutes state that the section was derived from Section 17 of the 1870 Act. Section 5510 is probably more properly considered an amalgamation of criminal provisions of the 1866 Act, the 1870 Act, and the 1871 "Ku Klux Klan" Act, as the Supreme Court has suggested. See Screws v. United States, 325 U.S. 91, 98-99 (1945) (noting the various historical sources of the law). Section 5510 criminalizes, in addition to conduct proscribed in Section 17, the deprivation of "privileges, or immunities" secured by the "Constitution and laws of the United States," which had been prohibited by the $1871 \mathrm{Ku}$ Klux Klan Act. See Ku Klux Klan Act of 1871, ch. 22, § 1, 17 Stat. 13, 13 ("[A]ny person who ... shall subject ... any person within the jurisdiction of the United States to the deprivation of any rights, privileges, or immunities secured by the Constitution or laws of the United States . .. shall ... be liable" to the injured party (emphasis added)). Representative Lawrence stated quite explicitly that the statute as proposed in Thomas 
largely followed the language of its sources, the codifiers changed the phrase "on account of such person being an alien" such an inhabitant being an alien," tracking the use of "inhabitant" earlier in the same section. ${ }^{81}$ The change was presumptively nonsubstantive and presumably intended for symmetry. ${ }^{82}$ But courts nonetheless scrutinized the use of "inhabitant" in later years (and applied it broadly). ${ }^{83}$ In 1994 Congress changed both instances of "inhabitant" to "person" to remove any doubt about the expansiveness of its coverage. ${ }^{84}$

In sum, by 1875 , the various overlapping and distinct elements of Sections 1 and 2 (from 1866) and Sections 16 and 17 (from 1870) were codified into four separate statutes:

- Most of Section 1 (from 1866) and Section 16 (from 1870) appeared in Section 1977, requiring equality of specified rights between persons and white citizens (the alien nondiscrimination provision).

- The original portion of Section 1 (from 1866) addressing property rights of citizens-that was not encompassed by Section 16 (from 1870) - was codified separately in Section 1978 (the citizen property discrimination provision).

Jefferson Durant's revision, which was ultimately adopted verbatim, "condenses into one the three criminal sections" of the 1866, 1870, and 1871 Acts. 2 CONG. REC. 828 (1874).

80. Civil Rights Act of 1870, ch. 114, $\$ 17,16$ Stat. 140, 144 (emphasis added).

81. Revised Statutes $§ 5510$ (emphasis added).

82. Any substantive change to the law would have run counter to the professed aim of the codifiers. See 2 CONG. REC. 129 (1873) (statement of Rep. Butler) ("We have not attempted to change the law, in a single word or letter, so as to make a different reading or different sense. All that has been done is to strike out the obsolete parts and to condense and consolidate and bring together statutes in pari materia ....").

83. For example, courts of appeals analyzed the term in determining the extent to which the statute might protect unlawfully present aliens. See United States v. Contreras, 950 F.2d 232, 243 (5th Cir. 1991) (finding that the presence of an "illegal alien" "was sufficiently permanent for her to qualify as an inhabitant under the statute"); United States v. Maravilla, 907 F.2d 216, 227 (1st Cir. 1990) ("We can understand how one might bring an 'illegal alien,' intending to stay in the country for some time, within the scope of the word 'inhabitant."'); United States v. Otherson, 637 F.2d 1276, 1285 (9th Cir. 1980) ("[T]he term 'inhabitant' as used in [S]ection 242 does include all persons, without exception, present within the jurisdiction of the United States.").

84. See Violent Crime Control and Law Enforcement Act of 1994, Pub. L. No. 103-322, § 320201(b)(2), 108 Stat. 1796 (striking references to "inhabitant" and inserting the term "person"); cf. 137 CONG. REC. 3191 (1991) (indicating that the intent of the change from "inhabitant" to "person" was "to ensure protection of all persons within the United States by these important provisions of the federal civil rights laws, regardless of whether they are (inhabitants"'). 
- The second sentence of Section 16 (from 1870) prohibiting discriminatory landing taxes appeared in Section 2164 (the landing tax provision).

- The expanded criminal provision of Section 17 (from 1870) prohibiting differential punishment on account of a person's "being an alien," and encompassing the former Section 2 (from 1866) (as well elements of the $1871 \mathrm{Ku}$ Klux Klan Act) appeared in Section $5510^{85}$ (the criminal alien discrimination provision).

\section{b. Later Changes: 1926 Codifications}

Over the next seventy-five years, the statutes eventually settled into their present location. Of particular interest, from 1926 until 1952 the alien non-discrimination provision codified at Section 1977 (from Section 16) appeared as part of the "Aliens and Citizenship" immigration laws in Title 8 of the United States Code. ${ }^{86}$

In 1926, the publication of the United States Code placed Section 1977 (prohibiting alienage discrimination) among the immigration laws at 8 U.S.C. $\S$ 41. The related Section 1978 (protecting property rights for citizens) was kept adjacent and codified at 8 U.S.C. $\S 42$. The two sections were a part of the "Civil Rights" chapter of the Aliens and Citizenship Title $8 .^{87}$ Both provisions remained a part of the Immigration title for more than a quarter-century.

The 1926 reorganization also renumbered the landing tax provision; what was once in Section 16, and then codified at Section 2164 in 1875, became Section 135 under the "Aliens and Citizenship" title in the "Immigration" chapter. ${ }^{88}$ It was later repealed in 1952 by the INA, which rendered that section superfluous. ${ }^{89}$

85. See supra note 79 (discussing the roots of Section 5510).

86. In 1926, the United States Code was published (prepared by private publishers under the supervision of House and Senate committees). See Fitzgerald, supra note 71 ("Under the auspices of the committees of the House and the Senate the actual work of assembling and classifying the mass of material has been done by the West Publishing Co. and the Edward Thompson Co.").

87. See 8 U.S.C. $\S \S 41-43$ (1926) (current version at 42 U.S.C. $\S \S 1981-83$ ). Today's 42 U.S.C. $\S 1983$ appeared at 8 U.S.C. § 43, and was previously Section 1979 of the Revised Statutes, which derived from Section 1 of the $1871 \mathrm{Ku}$ Klux Klan Act. See supra note 79. See also Monroe v. Pape, 365 U.S. 167, 204 (1961) (tracing the origins of the provision).

88. See 18 U.S.C. $§ 135$ (1926) (repealed 1952) (incorporating the landing tax provision).

89. See Immigration and Nationality Act, Pub. L. No. 82-414, § 403(a)(1), 66 Stat. 163, 279 (1952) (repealing Section 135). The 1952 notes to Title 8 explain that Section 135 was now covered in subchapter II of chapter 12, which contained provisions of the new INA. See 8 U.S.C. $\S 135$ (1926) (repealed 1952) (showing the relocation). 
Lastly, the 1926 codification moved the criminal provisions (originating in Section 17 of the 1870 Act) codified at Section 5510 in 1875 , to Section 52 of Title 18 , the Crimes title. ${ }^{90}$ Unlike the other sections, it had undergone an interim move in 1909 to section 20 of the Federal Penal Code. ${ }^{91}$ In 1948, Section 52 was renumbered as Section 242, where it remains today. ${ }^{92}$

\section{c. 1952}

The most recent changes in the statutes' locations occurred in 1952 when Congress enacted the INA. ${ }^{93}$ That overhaul of federal immigration law prompted further reorganization of the United States Code. The two civil rights provisions derived from the 1866 and 1870 Acts were moved out of the Immigration title (Title 8) and into the Health and Welfare title (Title 42). They became, respectively, 42 U.S.C. $\S \S 1981$ and 1982, where they have remained ever since. ${ }^{94}$

$$
\text { * * * }
$$

The chart below schematically portrays the evolving placement of the 1870 Act's immigration provisions culminating in the current codification of Sections 16 and 17 at 42 U.S.C. $\S 1981$ and 18 U.S.C. $\S$ 242.

The disaggregation, fragmentation, and transient codification of the protections for non-citizens in the 1870 Act that began with the 1875 codification process and continued with the subsequent scattering of the various provisions through the United States Code may help explain why the Supreme Court gradually lost sight of the broader significance of the 1870 Act as a whole. The codification process separated the parts of the Act from each other thereby diminishing the more encompassing nature of Senator Stewart's original bill and the relevant provisions of the 1870 Act. Section 17

90. See 18 U.S.C. $\$ 52$ (1926) (repealed 1948).

91. See Penal Code of 1909, ch. 321, § 20, 35 Stat. 1088, 1092.

92. See Act of Jan. 6, 1948, ch. 645, § 242, 62 Stat. 683, 696; 18 U.S.C. § 242 (1926) (repealed 1948) (containing the same content).

93. Immigration and Nationality Act.

94. See 8 U.S.C. $\$ \S 41-43$ (1952) (current version at 42 U.S.C. $\S \S 1981-83$ ) (indicating transfer); 42 U.S.C.A. $\$ 1981-82$ (West 2013) (containing the same content). The legislative sources do not reveal a reason for the shift in location. In 1991, § 1981 underwent a final significant substantive expansion to clarify the reach of the term "make and enforce contracts" and to specify that the statute covered non-governmental private discrimination as well as action under color of state law. See Civil Rights Act of 1991, Pub. L. No. 102-166, § 101, 105 Stat. 1071. See generally CBOCS W., Inc. v. Humphries, 553 U.S. 442, 450-51 (2008) (recounting enactment of 1991 Civil Rights Act amending 42 U.S.C. § 1981). 
(which criminalized forms of alienage discrimination) and the nowrepealed landing tax prohibition became separated from the nondiscrimination provision of Section 16, obscuring their shared history and broader goal of equality.

In addition, the central protections of Section 16 disappeared from the Immigration title when they were moved in 1952. After the codification of 1926, when the discrimination prohibition appeared in the federal scheme regulating-and protecting-immigrants, the immigration nexus was more immediately apparent. Transferring Section 16 out of the Immigration title of the Code in 1952 may have eventually clouded its origins as part of a broader framework that Congress enacted along with Section 17 to protect non-citizens against state alienage discrimination. 
Figure 1

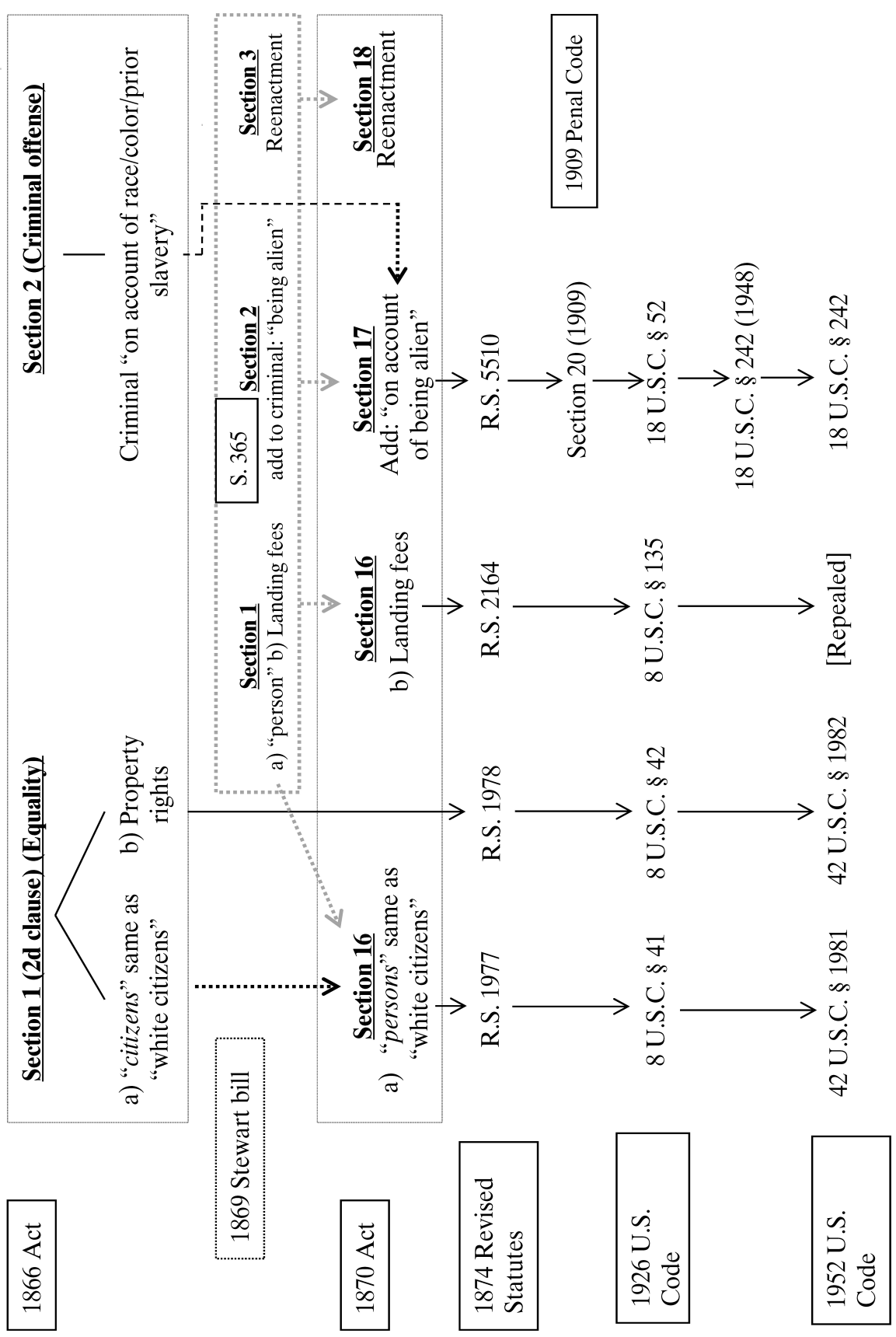




\section{B. The Court's Immigration Preemption Decisions and the 1870 Act}

For many decades following the enactment of the 1870 Civil Rights Act, the Supreme Court recognized the Act as a component of the federal structure that protects immigrants against state discrimination. The Court consciously invoked the Act in defining the federal law and federal interests that preempted state measures under the Supremacy Clause. The Act's provisions informed the Court's understanding of the broad federal framework governing the rights of immigrants and barring inconsistent state laws. The principal rulings in which the Court recognized Section 16 as part of a comprehensive federal scheme regulating and protecting aliens are Yick Wo v. Hopkins, Hines v. Davidowitz, ${ }^{95}$ Takahashi v. California Fish \& Game Commission, ${ }^{96}$ and Graham v. Richardson.

The 1870 Act first played a prominent role in defining the scope of federal law with the landmark case of Yick Wo v. Hopkins. In Yick Wo, the Court struck down sub-federal restrictions on aliens on the ground-for the first time-that the laws constituted impermissible discrimination. ${ }^{97}$ The case famously held that San Francisco laundry ordinances, although neutral on their face, discriminated impermissibly against Chinese immigrants in violation of the Fourteenth Amendment because "in their administration" they were "applied and administered" with "an evil eye and unequal hand."

The Court prominently relied on the 1870 Civil Rights Act in support of its ruling. ${ }^{99}$ Although it recognized that plaintiffs were "aliens and subjects of the emperor of China," nonetheless found that they were within the protections of the

\footnotetext{
95. 312 U.S. $52(1941)$.

96. 334 U.S. 410 (1948).

97. Yick Wo v. Hopkins, 118 U.S. 356, 374 (1886). Before Yick Wo, the Court had struck down some sub-federal laws governing foreign nationals on the ground that they constituted impermissible regulation of immigration. See Chy Lung v. Freeman, 92 U.S. 275, 277, 280-81 (1875) (holding that a California statute imposing state fees to control entry of paupers, criminals, and other undesirable immigrants constituted unconstitutional regulation of immigration); Henderson v. City of New York, 92 U.S. 259, 274 (1875) (invalidating a similar New York statute on the same grounds). The Court had also upheld other laws as permissible exercises of local power. See Soon Hing v. Crowley, 113 U.S. 703, 707, 711 (1885) (holding that a San Francisco ordinance limiting working hours in laundries was a valid exercise of police power); Barbier v. Connolly, 113 U.S. 27, 30 (1884) (holding that a related San Francisco ordinance was a valid exercise of police power).

98. Yick Wo, 118 U.S. at 373-74.

99. Id. at 369 .

100. Id. at 368 .
} 
Constitution—and of the Civil Rights Act of $1870 .^{101}$ The Court recited the Due Process and Equal Protection Clauses of the Fourteenth Amendment, and affirmed that " $\mathrm{t}]$ hese provisions are universal in their application, to all persons within the territorial jurisdiction, without regard to any difference of race, of color, or of nationality." 102 The Court went on to quote the key protection of Section 16 of the 1870 Act (by then codified at Section 1977):

It is accordingly enacted by section 1977 of the Revised Statutes that "all persons within the jurisdiction of the United States shall have the same right, in every state and territory, to make and enforce contracts, to sue, be parties, give evidence, and to the full and equal benefit of all laws and proceedings for the security of persons and property as is enjoyed by white citizens, and shall be subject to like punishment, pains, penalties, taxes, licenses, and exactions of every kind, and to no other., ${ }^{103}$

The Court strongly emphasized the equality principle embedded in the Act. It stressed that under the law the "rights of every citizen" must be viewed "equally with those of the strangers and aliens" seeking the Court's protection. ${ }^{104}$ The Court ultimately ruled that the law was based on "hostility to the race and nationality" of the plaintiffs, violating equal protection..$^{105}$ But the opinion laid the foundation for the 1870 Act's preeminence with regard to alienage discrimination.

In subsequent cases, Yick Wo's understanding about the scope and importance of the 1870 Civil Rights Act became central when the Court considered immigration preemption and the protection afforded by federal law. The language from Yick Wo and the invocation of Section 16 appeared in key cases where the Court struck down state laws solely on federal preemption grounds. ${ }^{106}$

101. Id. at 369 .

102. Id. (emphasis added). See also id. ("The fourteenth amendment to the constitution is not confined to the protection of citizens.").

103. Id.

104. Id.

105. Id. at 374 .

106. After Yick Wo, the Court considered a number of cases challenging state or local laws discriminating on the basis of alienage without considering Section 16. Most of these cases concerned inheritance or ownership of real property, an area specifically carved out of Section 16 of the 1870 Act. Those restrictions were permitted unless the Court found them prohibited by treaty or as discriminating against United States citizens (not aliens) based on nationality. Compare Cockrill v. California, 268 U.S. 258, 261-63 (1925) (upholding the discriminatory presumption created by the California Alien Land Law), and Terrace v. Thompson, 263 U.S. 197, 223-24 (1923) (upholding the Washington Alien Land Law, which restricted alien land 
In Hines v. Davidowitz, which Arizona cites prominently, ${ }^{107}$ the Court invalidated a Pennsylvania alien registration law. ${ }^{108}$ Hines concerned Pennsylvania's 1939 law requiring aliens to register annually and to provide specified information to the state. ${ }^{109}$ The plaintiffs claimed that the state law conflicted with a number of constitutional rights and federal provisions, including Section 16 of the 1870 Act (by then codified at 8 U.S.C. $\S 41) .{ }^{110}$

The Court expressly left open all other claims and ruled only on the plaintiffs' federal preemption claim. ${ }^{111}$ The opinion concluded that the state law was preempted by the recently enacted federal registration regime. ${ }^{112}$ In doing so, the Court, with Justice Black

ownership), and Porterfield v. Webb, 263 U.S. 225, 233 (1923) (upholding the California Alien Land Law, which restricted alien land ownership), and Petersen v. Iowa, 245 U.S. 170, 175 (1917) (upholding a discriminatory Iowa inheritance tax), and Duus v. Brown, 245 U.S. 176, 177-78 (1917) (same), with Oyama v. California, 332 U.S. 633, 636, 644-47 (1948) (holding a state land restriction unconstitutional as applied to an American citizen born to Japanese parents), and Nielsen v. Johnson, 279 U.S. 47, 57-58 (1929) (holding that a treaty with Denmark rendered Iowa's inheritance tax on Danish citizen unlawful), and De Geofroy v. Riggs, 133 U.S. 258, 272-73 (1890) (holding that a treaty with France rendered the District of Columbia's restriction on French citizen's inheritance unlawful). Other cases were decided under the Equal Protection Clause (without mention of preemption or the 1870 Civil Rights Act) under the thenprevailing view that public goods, employment, and resources could be reserved to United States citizens. See, e.g., Heim v. McCall, 239 U.S. 175, 176-77, 194 (1915) (upholding a New York law restricting public works hiring to citizens); Crane v. New York, 239 U.S. 195, 198 (1915) (upholding a law criminalizing the hiring of aliens for public works); Patsone v. Pennsylvania, 232 U.S. 138, 143-45 (1914) (upholding a law forbidding aliens from owning a shotgun or rifle and from "kill[ing] any wild bird or animal except in defense of person or property"). Interference with private employment was struck down on equal protection grounds. See, e.g., Truax v. Raich, 239 U.S. 33, 40-43 (1915) (holding unconstitutional an Arizona law imposing a general quota on the employment of lawfully admitted aliens). In Ohio v. Deckerbach, the Court upheld an Ohio law prohibiting aliens from operating pool halls, areas known for vice and corruption, as "rational" without mention of Section 16. 274 U.S. 392, 397 (1927). In 1971, Graham v. Richardson revolutionized the level of scrutiny applicable to state alienage discrimination, rendering obsolete and invalid most of the discriminatory laws that had previously been allowed. 403 U.S. 365, 371-72 (1971) ("[C]lassifications based on alienage, like those based on nationality or race, are inherently suspect and subject to close judicial scrutiny." (footnotes omitted) (citations omitted)).

107. Arizona v. United States, 132 S. Ct. 2492, 2501-03 (2012) (explaining Hines).

108. 312 U.S. 52, 74 (1941).

109. Id. at 59 .

110. Plaintiffs argued that the state law violated the Equal Protection Clause and Section 16 of the Civil Rights Act of 1870, exceeded Pennsylvania's constitutional power absent congressional consent, and was precluded by the comprehensive federal alien registration scheme. Id. at 61 \& n.7 (quoting Civil Rights Act of 1870, ch. 114, § 16, 16 Stat. 140, 144) (reciting Section 16 in its entirety). The Solicitor General's amicus brief on behalf of the United States supported plaintiffs' argument that the Pennsylvania statute was invalid under Section 16 of the 1870 Civil Rights Act. See Brief for United States as Amicus Curiae Supporting Respondents at 43-49, Hines, 312 U.S. 52 (No. 22).

111. Hines, 312 U.S. at 62.

112. Id. at 74 . 
writing, conducted "an examination of congressional enactments" to determine whether Congress has "acted in such matter" as to preclude enforcement of the state law. ${ }^{113}$ That in turn caused the Court to assess Congress's "broad and comprehensive plan" for alien admission, citizenship, and deportation. ${ }^{114}$ And that assessment incorporated the values reflected in treaty obligations and, separately, the protections of equality guaranteed by "[o]ur Constitution and our Civil Rights Act." 115

The Hines Court understood the 1870 Civil Rights Act as reflecting a non-discrimination mandate that, along with other sources of federal law, contributed to a "comprehensive scheme" for the treatment of aliens that preempted inconsistent state laws. Thus, while declining to find that Pennsylvania's law transgressed Section 16 directly, the Court nonetheless relied on the Civil Rights Act when it identified the umbrella of federal interests that preempted state statutes. The Court recognized the 1870 Civil Rights Act as important to defining the federal structure that governed the treatment of immigrants and as part of the overall legislative framework adopted by Congress setting the terms and conditions that govern aliens in the United States. ${ }^{116}$ Hines thus reflects an immigrant equality principle in the context of preempting state laws.

Hines also relied on the foreign affairs power as a source of the federal government's immigration authority. The Court explained the importance of federal primacy and the implications for foreign affairs and international relations if states were allowed to impose discriminatory burdens on aliens. ${ }^{17}$ The interference with national interests stemming from "real or imagined wrongs" to another nation's subjects could precipitate international tensions and reciprocal mistreatment that were matters of "national moment." "118

The threatened mistreatment of foreign nationals was part of Justice Black's broader theme that placed emphasis on the "rights, liberties and personal freedom of human beings." ${ }^{\text {"119 }}$ He noted that the danger of laws "singling out aliens as particularly dangerous and

113. Id. at $68-69$.

114. Id. at 69 .

115. Id. (emphasis added) (citing Yick Wo v. Hopkins, 118 U.S. 356, 369 (1886)).

116. Id.

117. Id. at $62-74$.

118. Id. at 64,73 .

119. Id. at 68 . 
undesirable groups" is "deep-seated in this country." ${ }^{120}$ He expressed concern throughout the opinion about the manifold ways in which foreign nationals could be harassed and targeted by "inquisitorial practices," "police surveillance," "injurious discrimination," "indiscriminate and repeated interception," "interrogation by public officials," "irritating restrictions upon personal liberties," and "indiscriminate questioning." 121 Black's discussion of preemption recognized the equality rights and liberty interests of the immigrants themselves that underscores the immigrant equality element of federal law. ${ }^{122}$

Soon after Hines, the Court decided Takahashi v. California Fish \& Game Commission, in which Section 16 also contributed to the invalidation of a state law targeting Japanese immigrants. ${ }^{123}$ Takahashi considered a World War II-era law, first enacted by California in 1943 during the period of Japanese-American internment, prohibiting issuance of commercial fishing licenses to any "alien Japanese."124 In 1945 the law was amended to remove the explicit reference to the Japanese and to bar instead any "person ineligible to citizenship.",

120. Id. at 70 .

121. Id. at $65-66,71,74$.

122. Id. at 70. Judith Resnik explains that Black's holding is imbedded in a discussion of "constituting American identity by limiting the power of the government to interfere with 'personal liberties." See Judith Resnik, Bordering by Law: The Migration of Law, Crimes, Sovereignty, and the Mail, (forthcoming 2013) (manuscript at 23, 30) (on file with author) (tracking the Hines Court's discussion of public registration laws as "at war with fundamental principles of our free government," and characterizing the opinion as "reject[ing] adding public stigmatization as a facet of the government alien-relationship" (citation omitted) (internal quotation marks omitted)).

123. 334 U.S. 410, 419 (1948).

124. Id. at 413. The law at issue in Takahashi was a transparent anti-Japanese statute. See id. at 426-27 (Murphy, J., concurring). The legislative history documented an amendment to the statute to make it appear less overtly race-based. Id. at 425-26 (discussing the legislative history).

125. Id. at 425. At that time, the Japanese remained ineligible to naturalize. $I d$. at 412 \& n.1. See also Oyama v. California, 332 U.S. 633, 665 n.20 (1948) (Murphy, J., concurring) (estimating that "[o]f the 48,158 aliens ineligible for naturalization [in the continental United States], 47,305 were Japanese, 749 were Korean, 9 were Polynesian, and 95 belonged to other Asiatic groups" (citing the 1940 United States Census)). This situation arose from the 1790 Act, which restricted naturalization eligibility to "free white person[s]." Act of Mar. 26, 1790, ch. 3, § 1, 1 Stat. 103, 103. A Reconstruction-era amendment extended eligibility to "persons of African descent." Act of July 14, 1870, ch. 254, § 7, 16 Stat. 254, 256. For many years only "whites" and persons of African origin or descent were eligible for naturalization. Substantial litigation concerned which persons could be considered "white." See, e.g., United States v. Singh Thind, 261 U.S. 204, 206, 215 (1923) (holding that a "Hindu" person is not white); Ozawa v. United States, 260 U.S. 178, 198 (1922) (holding that a Japanese person is not white). See generally John Tehranian, Note, Performing Whiteness: Naturalization Litigation and the Construction of Racial Identity in America, 109 YALE L.J. 817 (2000) (discussing litigation concerning the "whiteness" of various 
Takahashi was denied a license in 1945 under that law. ${ }^{126}$

The California Supreme Court upheld the restriction, ${ }^{127}$ and the Supreme Court granted review to consider both "federal-state relationships" and the Fourteenth Amendment. ${ }^{128}$ The Court appeared prepared to invalidate the restriction on Fourteenth Amendment grounds. ${ }^{129}$ However, that reasoning presented potential difficulties because it could cast doubt on a line of cases allowing state restrictions against aliens based on the "special public interest" rationale on which California relied. ${ }^{130}$ The Court avoided dismantling the public interest exception by deciding (in conclusory fashion at the end of the opinion) that the state's defense did not apply because California could not claim a sufficient "ownership" interest of fish within a three-mile coastal zone to justify exclusion of alien fishers under the Equal Protection Clause. ${ }^{131}$ Yet, the Court did not place

racial groups and legal methodologies of race). In 1919 and 1924, Congress granted citizenship to certain American Indians. Act of June 2, 1924, ch. 232, 43 Stat. 253 (granting citizenship to certain American Indians born in the United States); Act of Nov. 6, 1919, ch. 95, 41 Stat. 350 (granting citizenship to American Indians who served in the armed forces during World War I). A 1940 Act provided for naturalization of "descendants of races indigenous to the Western Hemisphere," Act of Oct. 14, 1940, ch. 876, § 303, 54 Stat. 1137, 1140, which was meant to extend to all American Indians, Charles Gordon, The Racial Barrier to American Citizenship, 93 U. PA. L. REV. 237, 239 (1945). Upon repealing the Chinese exclusion laws, Congress added persons of Chinese origin or descent to the list of racial groups eligible to naturalize in 1943. Act of Dec. 17, 1943, ch. 344, § 1, 57 Stat. 600, 600. In 1946, Filipinos and "persons of races indigenous to India" became eligible for citizenship. Luce-Celler Act, ch. 534, 60 Stat. 416 (1946). See generally Gerald E. Cronin, Immigration and Naturalization Laws, 7 U. DET. L.J. 105, 120-22 (1948) (describing the progression of case law and legislation in naturalization). Racial restrictions on naturalization were finally eliminated in 1952. See generally Immigration and Nationality Act of 1952, 66 Stat. 163; CHARLES GORDON ET AL., IMMIGRATION LAW AND PROCEDURE § 94.01(2).

126. Takahashi, 334 U.S. at 414.

127. Takahashi v. Fish \& Game Comm'n, 30 Cal. 2d 719 (1947), rev'd, 334 U.S. 410 (1948). The state court ruled that "in furtherance of its declared public policy to prohibit ineligible aliens from taking its animals ferae naturae," California could permissibly refuse to issue fishing licenses to ineligible aliens. $I d$. at 736-37.

128. Takahashi, 334 U.S. at 415.

129. Id. at 415-16.

130. Id. at 417. Takahashi also cited Truax v. Raich, 239 U.S. 33 (1915), for the "special public interest" doctrine, which in turn cited Patsone v. Pennsylvania, 232 U.S. 138, 145-46 (1914). See Patsone, 232 U.S. at 145-46 (upholding a statute prohibiting aliens from owning guns for purposes other than defense of self or property because states have the right to prohibit noncitizens from hunting their wild game); Blythe v. Hinckley, 180 U.S. 333, 340-41 (1901) (holding that states may restrict aliens' inheritance rights in the absence of a treaty); Hauenstein v. Lynham, 100 U.S. 483, 484 (1879) (holding that states may make laws restricting the rights of aliens to hold real property); McCready v. Virginia, 94 U.S. 391, 397 (1876) (holding that a state can reserve the right to plant oysters in its riverbanks to citizens of the state).

131. Takahashi, 334 U.S. at 421 (finding that "'ownership' is inadequate to justify California in excluding any or all aliens" lawfully in the state from fishing in coastal waters). 
exclusive reliance on a robust view of the Fourteenth Amendment's proscriptions. Rather, the Court began with a lengthy discussion of federal law and federal interests. It focused on the federal government's broad constitutional powers over the admission and regulation of aliens ${ }^{132}$ as well as the protections of the 1870 Act. $^{133}$

Takahashi underscored that states can neither "add to nor take from the conditions lawfully imposed by Congress on admission, naturalization and residence." ${ }^{134}$ The Court explained that "discriminatory burdens" on entrance or residence of aliens lawfully within the United States "conflict with th[e] constitutionally derived federal power to regulate immigration" and are invalid. ${ }^{135}$

However, and importantly, Takahashi did not rest exclusively on the federal power to regulate admission and expulsion of aliens. Takahashi-in an opinion again authored by Justice Black-also emphasized the affirmative prohibition against discrimination embodied in Section 16 of the 1870 Civil Rights Act. ${ }^{136}$ The Court conceptualized this anti-discrimination protection as centrally within Congress's enactment of a "comprehensive legislative plan for the nation-wide control and regulation of immigration and naturalization." ${ }^{137}$ Like Yick Wo, Takahashi quotes the text of Section 16 in its entirety and affirms its protection for aliens. ${ }^{138}$ The Court thus recognized that the congressional scheme encompassed both the

132. Id. at 419 ("The Federal Government has broad constitutional powers in determining what aliens shall be admitted to the United States, the period they may remain, regulation of their conduct before naturalization, and the terms and conditions of their naturalization." (citing Hines v. Davidowitz, 312 U.S. 52, 66 (1941))).

133. Id. at 419-20.

134. Id. In Takahashi, as well as in Truax v. Raich, 239 U.S. 33 (1915) - a case Takahashi cites prominently-the Court's Fourteenth Amendment analysis is infused with concern over state interference with federal authority in the event a state discriminated against an alien lawfully admitted to the United States. The Court referred to the protection afforded persons "lawfully" in the country and denied states power to single out and ban their "lawful" alien inhabitants. Takahashi, 344 U.S. at 419-20. As I discuss in Part III, infra, these references did not denude the 1870 Act of its power to preempt state laws that target aliens indiscriminately or that single out those who are unlawfully in the United States. See infra Part III and text accompanying notes 180-93.

135. Takahashi, 344 U.S. at 419.

136. Id.

137. Id. at 419 ("Congress, in the enactment of a comprehensive legislative plan for the nation-wide control and regulation of immigration and naturalization, has broadly provided [quoting Section 16 in its entirety].” (quoting 8 U.S.C. $\$ 41$ (1948))).

138. Id. 419 ("The protection of this section has been held to extend to aliens as well as to citizens." (citing United States v. Wong Kim Ark, 169 U.S. 649, 696 (1898); Yick Wo v. Hopkins, 118 U.S. 356, 369 (1886); Fraser v. McConway \& Torley Co., 82 F. 257 (C.C.D. Penn. 1897); In re Tiburcio Parrott, 1 F. 481, 508-09 (C.C.D. Cal. 1880))). 
immigration control and the immigrant equality strands of preemption in the "legislative plan" governing immigration and immigrants.

Takahashi is significant because it further demonstrates that the Civil Rights Act supports displacing state law to enforce equality even if the state discrimination does not obviously contradict the equal protection safeguards of the Fourteenth Amendment. In Takahashi, the California law teetered on the edge of Equal Protection vulnerability and the Court invoked Section 16 to buttress its analysis. ${ }^{139}$ The Court emphasized that the California statute was contrary to federal law, including the Civil Rights Act of $1870 .{ }^{140}$

Second, and notable for the contemporary debate, California tried to defend its law by arguing that it should be permitted to single out Japanese non-citizens because they were subject to discrimination and disabilities under federal law. The State urged that it was "simply follow[ing] the Federal Government's lead"141 and "adopting [the] classification from the naturalization laws." ${ }^{142}$ The Takahashi Court

139. Takahashi, 334 U.S. at 417-18. As Justice Brennan explained for the Court in Toll v. Moreno: "While pre-emption played a significant role in the Court's analysis in Takahashi, the actual basis for invalidation of the California statute was apparently the Equal Protection Clause of the Constitution." 458 U.S. 1, 11 n.16 (1982). Brennan emphasized, however, that "many of the Court's decisions concerning alienage classifications, such as Takahashi, are better explained in pre-emption than in equal protection terms." Id. (citing Michael J. Perry, Modern Equal Protection: A Conceptualization and Appraisal, 79 CoLUM. L. REV. 1023, 1060-65 (1979); David F. Levi, Note, The Equal Treatment of Aliens: Preemption or Equal Protection?, 31 STAN. L. REV. 1069 (1979)).

140. In some cases, where under existing doctrine the Equal Protection Clause does not clearly bar a state statute because strict scrutiny may not apply, the equality element of preemption plays a paramount role. Hiroshi Motomura more ambitiously suggests that Equal Protection itself should limit state immigration enforcement laws targeting undocumented immigrants on the ground that such statutes may lead to discrimination. See generally Motomura, supra note 9, at 2063-65; Hiroshi Motomura, The Rights of Others: Legal Claims and Immigration Outside the Law, 59 DUKE L.J. 1723, 1742-44 (2010). The preemption framework I advance here should strengthen Motomura's claim by providing historical and normative support for an anti-discrimination principle derived from federal law and applicable broadly to protect all non-citizens.

141. Takahashi, 334 U.S. at 418.

142. Id. California's claim thus echoed contemporary "mirror image" arguments asserting that states should be permitted to penalize aliens disfavored under federal law by "mirroring" the federal classification. See Kris W. Kobach, Reinforcing the Rule of Law: What States Can and Should Do to Reduce Illegal Immigration, 22 GEO. IMMIGR. L.J. 459, 465, 475-77 (2008) (arguing that the "mirror image" is an area where states can act constitutionally in the field of immigration). As I explain elsewhere, that theory lost any claim to legitimacy after Arizona $v$. United States. Guttentag, Immigration Preemption, supra note 11, at 35-42. Takahashi's rejection of California's arguments was underscored in Toll v. Moreno when Justice Rehnquist in dissent unsuccessfully sought to recast the Takahashi decision to permit state laws disfavoring some non-citizens so long as the law in question was consistent with federal immigration 
rejected that justification as inconsistent with both the Fourteenth Amendment and the laws "adopted under its authority." stressed again that Section 16 "extends to aliens as well as to citizens," "144 and, importantly, that the law protects "“all persons' against state legislation bearing unequally upon them either because of alienage or color." ${ }^{145}$

Finally, in Graham v. Richardson the Court discussed the equalitybased preemption principle more expansively. Graham concerned state welfare statutes from Arizona and Pennsylvania imposing discriminatory restrictions on immigrant eligibility for state benefits programs. ${ }^{146}$ The Court held that the restrictions violated the Equal Protection Clause. ${ }^{147}$ The Fourteenth Amendment ruling marked a sea change in equal protection doctrine ${ }^{148}$ establishing alienage as a suspect classification and subjecting state immigration classifications

criteria. See 458 U.S. at 27 (Rehnquist, J., dissenting). The Court rejected that assertion. Id. at 11 ("We rejected the argument [in Takahashi that the state had 'simply followed the Federal Government's lead'] stressing the delicate nature of the federal-state relationship in regulating aliens....").

143. Takahashi, 334 U.S. at 420. See also id. at 419 ("It does not follow ... that because the United States regulates immigration and naturalization in part on the basis of race and color classifications, a state can adopt one or more of the same classifications . . .."); id. at 420 ("[T]he power of the state to apply its laws exclusively to its alien inhabitants as a class is confined within narrow limits.").

144. Id. at 419 .

145. Id. at 420 (emphasis added) (citing Hurd v. Hodge, 344 U.S. 24, 33 (1948)).

146. Graham v. Richardson, 403 U.S. 365, 366-68 (1971).

147. Id. at 376. Eight Justices joined the Court's opinion holding that state "alienage" classifications are subject to strict scrutiny. Id. at 371-72. The Arizona statute limited eligibility for state disability assistance programs (funded in part by federal grants) to United States citizens and to legal resident aliens who had resided in the country for at least fifteen years. $I d$. at 366-67. The Pennsylvania statute limited eligibility for state welfare benefits (funded entirely by the state) to United States citizens, excluding all aliens. Id. at 368 .

148. Id. at 371-72. See, e.g., Earl M. Maltz, Citizenship and the Constitution: A History and Critique of the Supreme Court's Alienage Jurisprudence, 28 ARIZ. ST. L.J. 1135, 1164 (1996) (characterizing Graham as the "modern approach" to equal protection analysis); Levi, supra note 139, 1069-70 (noting the significance of Graham for equal protection jurisprudence). See generally JOHN HART ELY, DEMOCRACY AND DISTRUST: A THEORY OF JUDICIAL REVIEW 161-62 (1980) (calling the application of heightened scrutiny to alienage classifications a "relatively easy case"). See also id. at 148-49, 151 (tracing the level of scrutiny applied to alienage classifications). The understanding that state or local laws denying equal rights to immigrants may violate the Equal Protection Clause under some circumstances predated Graham. Most notably, after Yick Wo, in Truax v. Raich the Court held that an Arizona law limiting private employment of aliens violated their equal protection rights. 239 U.S. 33, 43 (1915). But that Equal Protection principle was limited by earlier decisions affirming a "special public interest" exception, which permitted alienage discrimination by public entities in the distribution of public goods or contracts. See, e.g., Heim v. McCall, 239 U.S. 175, 193-94 (1915) (applying the exception to a statute prohibiting noncitizens from employment on public works). See supra note 106. 
to strict scrutiny. ${ }^{149}$ This imposed new and insurmountable hurdles for most state restrictions based on alienage. ${ }^{150}$

The equal protection ruling, however, overshadowed Graham's second-and independent-holding that the state welfare restrictions were also preempted by federal law under the Supremacy Clause. ${ }^{151}$ That portion of the decision is easily overlooked and generally underappreciated. The Court held that-independent of Equal Protection-an "additional reason" for invalidating the state laws was based on the "constitutional scrutiny emerg[ing] from ... federal-state relations." 152 The Court determined that the state welfare laws were invalid as in "conflict with ... overriding national policies" for several reasons. ${ }^{153}$ Importantly, those reasons were not limited to the immigration law or federal enforcement power rationale for preemption (i.e., immigration control). They also included the immigrant protections enacted by Section 16 reflecting the immigrant equality component of federal law. ${ }^{154}$

To be sure, the Court began by noting the "comprehensive plan for the regulation of immigration and naturalization." 155 Thus, it stressed the federal government's "broad constitutional powers" over

149. Graham, 403 U.S. at 371-72.

150. After Graham, the Court developed the "political function" exception to acknowledge areas of political self-definition where states could permissibly exclude non-citizens. See Foley v. Connelie, 435 U.S. 291, 299-300 (1978) (holding the exception applicable to a statute barring aliens from becoming state troopers); Sugarman v. Dougall, 413 U.S. 634, 642-43 (1973) (establishing the "political function" exception).

151. Graham, 403 U.S. at 376-77 ("An additional reason why the state statutes do not withstand constitutional scrutiny emerges from the area of federal-state relations."). Justice Harlan joined only the preemption holding. Id. at 383 (Harlan, J., joining in part and in judgment). Considerable scholarship addresses the role of equal protection versus preemption rationales in immigration federalism cases. See, e.g., Harold Hongju Koh, From Graham to Bernal: Justice Blackmun's Equal Protection Theory of Aliens' Rights, 8 HAMLINE L. REV. 52, 58-60 (1985) (discussing Graham's dual equal protection and preemption holdings); Perry, supra note 139, 1060-64 (arguing that the Court's immigration federalism jurisprudence is better explained as preemption than equal protection); Levi, supra note 139, at 1070 (arguing that Graham and other immigration federalism cases "follow[] an unarticulated theory of preemption").

152. Graham, 403 U.S. at 376-77.

153. Id. at 378 ("State laws that restrict the eligibility of aliens for welfare benefits merely because of their alienage conflict with these overriding policies in an area constitutionally entrusted to the Federal Government.").

154. Id. at 377.

155. Id. The Court stated that immigration regulation was "constitutionally entrusted" to the federal government. See DeCanas v. Bica, 424 U.S. 351, 354 (1976) ("Power to regulate immigration is unquestionably exclusively a federal power."). But see Arizona v. United States, 132 S. Ct. 2492, 2511-15 (2012) (Scalia, J., dissenting) (arguing that states possess some authority to regulate immigration). 
aliens' admission, duration of stay, conditions on residency, and naturalization. ${ }^{156}$ The opinion elaborated on Congress's "comprehensive plan" enumerating the grounds of exclusion (i.e., denial of entry at the border) and deportation (i.e., expulsion after entering or being admitted) that concern indigency, poverty, or the likelihood of becoming a "public charge." ${ }^{157}$ Reasoning by inference, the Court stressed that "Congress has not seen fit to impose any burden or restriction on aliens who become indigent after their entry into the United States." ${ }^{158}$ Thus, the state prohibitions were not enforcing federal immigration restrictions.

However, after laying out those rationales derived from the immigration regulation and control dimension of federal law, Graham pivoted to the anti-discrimination mandate of Section $16 .{ }^{159}$ After quoting it at length, ${ }^{160}$ the Court emphasized that " $[t]$ he protection of this statute" had long been held "to extend to aliens as well as to citizens," conceived "overriding national policies" that regulate immigrants and protect them against discrimination. ${ }^{162}$

Graham reinforces the understanding that the Civil Rights Act embodies a transcendent federal principle prohibiting discrimination based on alienage. In earlier cases, like Yick Wo and Takahashi, issues of alienage discrimination had been conjoined with hostility based on race and ethnicity. ${ }^{163}$ Hence the pure alienage non-discrimination mandate of Section 16 may not have been operating alone. In Graham

156. Graham, 403 U.S. at 377 (quoting Takahashi v. Fish \& Game Comm'n, 334 U.S. 410, 419 (1948)). Among the cases the Court cites are the canonical sources of the federal "plenary power." See, e.g., Harisiades v. Shaughnessy, 342 U.S. 580 (1952); Fong Yue Ting v. United States, 149 U.S. 698 (1893). The Court also cites two essential preemption cases: Takahashi and Hines.

157. Graham, 403 U.S. at 377.

158. Id.

159. Id. By then the provision was codified at 42 U.S.C. $\S 1981$.

160. Id. ("[Congress] has broadly declared: "All persons within the jurisdiction of the United States shall have the same right in every State and Territory . . . to the full and equal benefit of all laws and proceedings for the security of persons and property as is enjoyed by white citizens."' (quoting 42 U.S.C. $\$ 1981)$ ).

161. Id. (citing Takahashi, 334 U.S. at 419); see also id. at 378 ("[A]liens lawfully within this country have a right to enter and abide in any State in the Union 'on an equality of legal privileges with all citizens under nondiscriminatory laws." (quoting Takahashi, 334 U.S. at 420)).

162. Id. at 378 ("State laws that restrict the eligibility of aliens for welfare benefits merely because of their alienage conflict with these overriding national policies in an area constitutionally entrusted to the Federal Government.").

163. Yick Wo targeted Chinese immigrants and Takahashi singled out Japanese. See supra text accompanying notes 97 and 124 . 
there was no discernible racial component, and the Court rejected the Pennsylvania and Arizona laws without any reference to race or nationality. Graham invoked the Civil Rights Act equality principle to show inconsistency with the "comprehensive [federal] plan" where the state discrimination was purely on the basis of alienage without any need to find immigration status serving as a proxy for ethnic or race-based animosity.

Critically, the Court in Graham recognized that Section 16's nondiscrimination mandate is an important element of the federal framework that defines "the overriding national policies" limiting state autonomy ${ }^{164}$ The Court employed an encompassing view of the federal laws and purposes that constitute the federal structure governing — and protecting-immigrants. The decision rested not just on the laws relating to admission and expulsion but also on the civil rights command of equality for non-citizens. The Court's analysis stands unmistakably for the principle that the preemptive force of federal law derives not just from immigration-control statutes that regulate the admission, expulsion, and residence of non-citizens; preemption also enforces the prohibitions against discrimination originating in the Civil Rights Act of 1870. Graham's preemption analysis effectuated both the immigration control and the immigrant equality ground. The two in tandem comprise the federal policies against which state restrictions must be measured.

$$
* * *
$$

After Graham, the Court's resolution of challenges to state alienage classifications has turned almost exclusively on whether the restrictions violate the Equal Protection Clause. ${ }^{165}$ The Supreme Court decided only two immigration cases on federal preemption grounds between 1971 and 2011. ${ }^{166}$ One, DeCanas v. Bica, ${ }^{167}$ held that a state

164. Graham, 403 U.S. at 378.

165. The Court decided numerous cases that applied strict scrutiny and that articulated the "political function" exception to heightened scrutiny of state classifications. See supra note 150. See also Guttentag, Immigration Preemption, supra note 11, at $4 \mathrm{n} .12$ (collecting post-Graham cases addressing state alienage restrictions).

166. Toll v. Moreno, 458 U.S. 1, 4, 17 (1982) (holding a university policy denying certain aliens in-state status preempted by federal immigration laws); DeCanas v. Bica, 424 U.S. 351, 352, 356 (1976) (upholding a California statute penalizing employers for knowingly hiring illegal aliens as an exercise of traditional state power); see also Douglas v. Seacoast Products, 431 U.S. 265, 282-83 (1977) (holding a Virginia statute restricting fishing licenses based on citizenship preempted by the Enrollment and Licensing Act and the federal scheme of fishing licensing and regulation).

167. 424 U.S. 351 (1976). 
alien employment regulation was within the state's historic police powers and, moreover, implicitly authorized by federal law, thus rejecting the federal preemption claim. ${ }^{168}$ The other, Toll v. Moreno, ${ }^{169}$ found that the state policy denying equal access to in-state tuition to certain "non-immigrant" foreign nationals temporarily residing in the country was inconsistent with their treatment under federal immigration (and other) laws, though the Court did not expressly rely on or invoke the Civil Rights Act. ${ }^{170}$

The Court did not hear another immigration preemption case until Chamber of Commerce v. Whiting. ${ }^{171}$ By then Section 16 and the equality principle it embodied had not been cited by the Court in an immigration case for nearly forty years. ${ }^{172}$ Today, equality-based

168. In DeCanas, a state law penalized agricultural employers who hired immigrant workers not lawfully eligible to work under federal law. Id. at 359-61. The Court upheld the employer sanctions law as not categorically prohibited on field preemption grounds and as falling within the traditional powers of the state in a realm in which the federal government exhibited only peripheral concern with immigrant employment. $I d$. at 365 . The case was remanded for consideration of conflict preemption. $I d$. at 360 . No reference to the 1870 Act appears in that decision. The role that this protection should play in the DeCanas setting, had the Court considered it, is complex. In Toll v. Moreno, the Court explained that federal law affirmatively authorized the California statute upheld in DeCanas. 458 U.S. 1, 47 n.18 (1982). On that reading, the state law would presumably not be preempted. Had the Court engaged in a broad canvassing of the applicable federal law, it should have considered the effect of the nondiscrimination rule reflected in Section 16 and whether the California statute posed a threat of discrimination either in the Court's field preemption ruling or as encompassed within the remand for conflict preemption.

169. 458 U.S. 1 (1982).

170. The Court invalidated a state tuition policy denying in-state tuition rates to certain non-immigrant visa holders as conflicting with federal law. Id. at 4, 17. The Court quoted Takahashi at length, $i d$. at 11 , read it as an equal protection case with significant preemption elements, id. at 12, and referred elliptically to its passages implicating Section 16 without directly citing them, id. at 12-13. Justices Brennan and Rehnquist sparred over the proper reading of Takahashi, with the majority rejecting Rehnquist's view. See supra note 142.

171. 131 S. Ct. 1968 (2011). See Guttentag, Immigration Preemption, supra note 11, at 4-7 (discussing and enumerating alienage discrimination cases after Takahashi until Arizona).

172. During that period, lower courts disagreed over the reach of $\S 1981$ 's application to private conduct, including private alienage discrimination. After the Supreme Court held that $\S$ 1981 applied to private race discrimination, see Runyon v. McCrary, 427 U.S. 160, 169-70 (1976) (holding that $\S 1981$ prohibits private race discrimination), the lower courts took up the issue of whether private alienage discrimination was also prohibited, see Bhandari v. First Nat'l Bank of Commerce, 829 F.2d 1343, 1351-42 (5th Cir. 1987) (holding that $\$ 1981$ does not reach private alienage discrimination committed under color of state law); Guerra v. Manchester Terminal Corp., 498 F.2d 641, 653-54 (5th Cir.1974) (holding that $\S 1981$ reaches private alienage discrimination). See also Duane v. GEICO, 37 F.3d 1036, 1043 (4th Cir. 1994) (holding that $\S$ 1981 prohibited private alienage discrimination). The issue was rendered moot by a 1991 amendment to $\S 1981$ that added explicit language covering private conduct. See Civil Rights Act of 1991, Pub. L. No. 102-166, §101, 105 Stat. 1071, 1071 ("The rights protected by this section are protected against impairment by nongovernmental discrimination and impairment under color of State law.”); Anderson v. Conboy, 156 F.3d 167, 169 (2d Cir. 1998) (holding that 
concerns appear reserved for Equal Protection claims, and preemption has become defined by immigration enforcement and regulation considerations. As the Court begins to grapple with contemporary sub-federal laws and to elaborate the scope and purposes of the federal framework regulating and protecting foreign nationals in the United States, the immigrant equality protection spawned by the Civil Rights Act of 1870 has a vital role to play.

\section{PREEMPTION AND EQUALITY}

The preceding account seeks to show that protecting non-citizens against sub-federal discrimination was a central and deliberate purpose of the Civil Rights Act of 1870, that the Act constitutes an essential component of federal policy, and that the Supreme Court has recognized-and enforced-the Act's immigrant equality safeguard in its Supremacy Clause analysis to preempt inconsistent state laws.

In the contemporary context, revitalizing the equality element of preemption has important consequences. First, it would oblige courts to assess whether local immigration measures are inconsistent with federal civil rights principles. That means preemption would look at more than the express or implicit limits on local enforcement that might be present in federal immigration control law; preemption would properly be concerned as well with the discriminatory consequences of state and local measures.

Second, the immigrant equality component of federal law illuminates a fundamental distinction between two types of contemporary local laws based on whether they advance or retard the equality of non-citizens. Local measures that further equality and reduce discrimination-i.e., immigrant-friendly (or so-called "sanctuary") laws-find affirmative support in the federal framework. In contrast, local laws that diminish equality or engender discrimination are at odds with federal equality goals. Immigrant equality is a federal objective rooted in congressional enactments that differentiates among categories of local immigration laws and

\footnotetext{
$\S 1981$ prohibited private alienage discrimination, "at least" since the 1991 Act). The 1991 amendment also resolved other disagreements about the scope of $\S 1981$ 's substantive protections. See generally CBOCS W., Inc. v. Humphries, 553 U.S. 442, 449-51 (2008) (explaining that the 1991 Act superseded the holding of Patterson v. McLean, 491 U.S. 164 (1989) and other cases in which the Court found that $\S 1981$ did not cover post-hiring discrimination). See supra note 94.
} 
ordinances.

\section{A. Enforcing Non-Discrimination}

The value the federal statutory scheme places on non-discrimination means that courts considering preemption should scrutinize whether state immigration laws cause discrimination against immigrants in addition to whether they constitute impermissible enforcement mechanisms. The immigration control approach adopted in Arizona asks whether a state law or practice exceeds the enforcement authority delegated to the state and whether it pierces a functional ceiling on the enforcement methods authorized by federal law. The immigrant equality component would also inquire into the danger of immigration discrimination that a state law poses.

For example, in Arizona, the Court's assessment of Section 2B's "show me your papers" law focused on whether the state detention and verification scheme might exceed federal enforcement authorization. Because the Court found that federal law required the Law Enforcement Support Center to respond to state inquiries about immigration status, the Court found no clear inconsistency between Section 2B's mandated inquiry and the federal enforcement scheme. ${ }^{173}$ The Court thus rejected a facial preemption claim. ${ }^{174}$ Though alluding to discrimination concerns, the Court did not evaluate Section 2B against an affirmative federal non-discrimination requirement. If immigrant equality were acknowledged as a core value of federal law, evidence that Section 2B increases the danger of profiling or discrimination would properly be part of the preemption analysis rather than be marginalized as an entirely distinct claim. ${ }^{175}$

173. Arizona v. United States, 132 S. Ct. 2492, 2508 (2012).

174. Id. As I have noted elsewhere, the Court imposed significant limits on Section $2 \mathrm{~B}$. Guttentag, Immigration Preemption, supra note 11, at 13-15.

175. See supra note 33 and accompanying text. 
Similarly, contemporary measures that single out or stigmatize non-citizens seeking access to the civil or criminal justice system, ${ }^{176}$ restrict eligibility for housing based on immigration status, ${ }^{177}$ or impede immigrants' attendance at public schools ${ }^{178}$ would be vulnerable to preemption under the immigrant equality prong. Although such enforcement measures may also be invalid under the Arizona immigration control paradigm, that framework is not the only basis for determining congressional objectives and the scope of preemption. Some state laws that oblige local officials to transmit certain immigration information to federal agencies may be thought to fit within the permissible immigration control ceiling. They may appear congruent with federal information-sharing policies and may not implicate the prolonged or uninvited police detention that Arizona disapproved. But such laws may nonetheless single out immigrants for separate treatment, impose discriminatory burdens, or encourage disparate effects. State immigration enforcement laws that generate ethnic stereotyping or incentivize racial profiling would be inconsistent with federal non-discrimination values. ${ }^{179}$ Preemption should take into account the law's interference with the federal purpose of immigrant equality.

176. See, e.g., ALA. CODE $\S 31-13-32$ (2012) (requiring the name of an "unlawfully present alien" who is detained by law enforcement and appears in state court to be posted). The provision is the subject of litigation. See Complaint for Declaratory and Injunctive Relief, Doe v. Hobson, No. 2:13-cv-00079-WKW-CSC (M.D. Ala. Feb 7, 2013).

177. Compare Lozano v. City of Hazleton, No. 07-3531, 2013 WL 3855549, *1 (3d Cir. July 26,2013 ) (holding a city ordinance that attempted to regulate "the provision of rental housing to aliens lacking lawful immigration status" within the city preempted by federal law), and Villas at Parkside Partners v. City of Farmers Branch, No. 10-10751, 2013 WL 3791664, *1-2 (5th Cir. July 22, 2013) (holding a city ordinance that sought to bar non-citizens "not lawfully present in the United States" from renting housing in the city preempted by federal law), with Keller v. City of Fremont, 719 F.3d 931, 937-38 (8th Cir. 2013) (holding a city ordinance that made it unlawful to rent, or permit occupancy by, an "alien not lawfully present in the United States" within the city not preempted by federal law).

178. See Hispanic Interest Coal. v. Governor of Ala. (HICA), 691 F.3d 1236, 1244-50 (11th Cir. 2012) (remanding for injunction against ALA. CODE $\S 31-13-27$, which required Alabama education officials to collect data about the alienage of public K-12 students and their parents). See also Plyler v. Doe, 457 U.S. 202, 223 (1982) (holding that discrimination against undocumented children in K-12 public school is subject to heightened scrutiny).

179. This Article does not attempt an exhaustive survey of current or potential state and local measures. My goal is to broaden the framework for preemption analysis of sub-federal laws. Whether any particular state or local law or policy is actually preempted necessarily turns on a careful reading of the specific state measure and federal provisions at issue. 
The fact that laws like SB 1070 purport to target only undocumented immigrants does not negate the non-discrimination command of the Civil Rights Act as an essential element of preemption. To be sure, the Court's earlier cases invoking Section 16 as part of the federal framework often focused on the "lawful" status of the immigrants affected by sub-federal laws. ${ }^{180}$ But equality retains its force as a goal of federal law-even if states claim to single out only those who are not lawful or documented.

That is the case because, among other reasons, laws that purport to focus on unauthorized aliens typically encourage scrutiny based on suspicion of undocumented status. This inevitably ensnares many lawful residents and citizens who share the assumed or stereotypical traits of suspected undocumented immigrants. ${ }^{181}$ More fundamentally, Sections 16 and 17 of the Civil Rights Act of 1870 are broad in their coverage and neither distinguishes between lawfully and unlawfully present immigrants. Section 16 applies to "all persons" and ensures their equality with "citizens" in "every State and Territory." 17 outlaws subjecting individuals to differential treatment or punishment on account of "being an alien." 183 There is no textual limitation or suggestion that only some aliens are protected and that others may be subjected to differential state sanctions or punishments. ${ }^{184}$ When Yick Wo first confronted the 1870 Act (along with the text and scope of the Fourteenth Amendment), the Court

180. See supra note 134 and accompanying text.

181. Considering the impact on lawful immigrants for preemption purposes is distinct from whether $\S 1981$ would itself be directly violated by an ordinance that lacks the requisite discriminatory purpose. The Court has held that 42 U.S.C. $\S 1981$ requires a showing of purposeful discrimination. See, e.g., Patterson v. McLean Credit Union, 491 U.S. 164, 186 (1989) (noting that $\S 1981$ requires a showing of "purposeful discrimination"). Even if one assumed that only lawful aliens were protected by $\S 1981$, which is contrary to the text, that would not answer the broader question of whether a local ordinance aimed only at undocumented immigrants that demonstrably precipitates or raises the danger of alienage discrimination-even if not purposeful-against lawful residents (through ethnic profiling or by other means) nonetheless interferes with federal policy or constitutes an obstacle to a federal goal.

182. Civil Rights Act of 1870, ch. 114, § 16, 16 Stat. 140, 144.

183. Id. $\$ 17$.

184. The lower courts have applied Section 17's protections generally to undocumented aliens. See United States v. Contreras, 950 F.2d 232, 243-44 (5th Cir. 1991) (upholding a conviction under 18 U.S.C. \$ 242 although the victim was an "illegal alien"). The term "inhabitant" may not have had as broad a scope (before it was amended to "persons"), but that term did not turn on an alien's immigration status under federal law. See United States v. Maravilla, 907 F.2d 216, 227-28 (1st Cir. 1990) (overturning a conviction where the alleged victim was a temporary visitor, though acknowledging that "[w]e can understand how one might bring an 'illegal alien,' intending to stay in the country for some time, within the scope of the word 'inhabitant'"). See also supra note 66. 
emphasized that the protection applied to all-including "aliens and subjects of the Emperor of China" ${ }^{\text {185 }}$ and that it mandated an equality of rights between citizens and those of "strangers and aliens." 186

Some might argue that the 1870 Act (and the language of Yick Wo) should not apply fully when states target undocumented immigrants because the Act predates the major federal immigration regulation adopted in 1875 and thereafter. Hence, the argument contends, Congress could not have intended to protect aliens who were in the country in violation of federal law. This fails to grapple with the broader effect on immigrant equality of laws even when they formalistically target only some non-citizens. The argument also fails to recognize the existence of some federal immigration regulation at the time of the 1870 Act (and extensive regulation by the time of Yick Wo). Federal legislation prohibited entry of some foreigners as early as 1862 -before passage of the 1870 Civil Rights Act. ${ }^{187}$ The Act's reference to "all persons" would, by its plain language, apply to persons present in the United States in violation of any earlier restrictions. $^{188}$

185. Yick Wo v. Hopkins, 118 U.S. 356, 368 (1886).

186. Id. at 369 .

187. For example, as commentators have noted, 1862 legislation prohibited the importation of "Coolies" from China and 1869 legislation extended the restriction to Japan and other Asian countries. See supra note 78. Many commentators understand the 1862 Act as a regulation of immigration. See, e.g., Gabriel J. Chin, Regulating Race: Asian Exclusion and the Administrative State, 37 HARV. C.R.-C.L. L. REV. 1, 10 (2002) ("[The Act] was intended to prevent the importation of 'Coolies' . . .."); Sarah H. Cleveland, Powers Inherent in Sovereignty: Indians, Aliens, Territories, and the Nineteenth Century Origins of Plenary Power over Foreign Affairs, 81 TEX. L. REV. 1, 114 (2002) ("Anti-Chinese sentiment also was prevalent at the national level. In 1862, Congress prohibited involuntary Asian immigration, and the 1875 Page Act again barred involuntary 'Oriental' laborers, as well as convicts and prostitutes."); Renee C. Redman, From Importation of Slaves to Migration of Laborers: The Struggle to Outlaw American Participation in the Chinese Coolie Trade and the Seeds of United States Immigration Law, 3 ALB. Gov'T L. REV. 1, 49 (2010) ("[The [1875] Law was not the first federal law to regulate immigration. It amended the Coolie Trade Prohibition Act, of February 19, 1862 . ..."). See also Arizona v. United States, 137 S. Ct. 2492, 2513 (2012) (Scalia, J., dissenting). But see Kerry Abrams, Polygamy, Prostitution, and the Federalization of Immigration Law, 105 COLUM. L. REV. 641, 668-69 (2005) (arguing that the 1862 Act was intended to prohibit American involvement in the slave trade, not to restrict immigration). Further, as Gerald Neuman has shown, states too had enacted laws regulating the entry of persons into states and their right to remain once present. Gerald L. Neuman, The Lost Century of American Immigration Law, 93 COLUM. L. REV. 1833, 1901 (1993). He explains that persons considered illegally present under state law would appear to have been understood to be "an illegal immigrant to the United States." Id.

188. Of course, by the time of Yick Wo in 1886 Congress had enacted the major immigration regulation and restriction laws of 1875 and 1882. See generally E.P. HUTCHINSON, LEGISLATIVE History OF AMERICAN IMMIGRATION POLICY 1798-1965 46 (1981) ("The complaints about the coming of foreign paupers, criminals, and other undesirables, long familiar 
It also bears recalling that Chinese immigrants of the midnineteenth century were the most disfavored and stigmatized category of non-citizens under federal law. The Chinese were subject to pernicious and discriminatory exclusion and deportation laws, ${ }^{189}$ were barred from the polity and ineligible for naturalization, ${ }^{190}$ were threatened with perpetual non-citizenship until the Supreme Court intervened in United States v. Wong Kim Ark, ${ }^{191}$ and were treated as disreputable and untrustworthy under federal law. ${ }^{192}$ Yet, Congress granted them a measure of civil rights equality and protection by consciously sweeping them into the scope of an historic and enduring Civil Rights Acts that denied states the authority to "follow the lead" of federal law. ${ }^{193}$ Federal disfavor or disability does not authorize state discrimination.

\section{B. Advancing Equality}

Recognizing the immigrant equality element of federal law also suggests an important conceptual difference between local measures that seek to further immigrant equality and those that seek to enforce immigration status violations.

Laws that support immigrant equality or integration should be understood as affirmatively furthering the anti-discrimination, immigrant-equality purposes of federal law. These local measures may, for example, instruct local police departments not to gather immigration information or not to enforce immigration status violations ${ }^{194}$ they may provide equal eligibility for in-state tuition at

to the colonial and state governments, were repeatedly heard in Congress."). My point is not that the 1870 Civil Rights Act necessarily outlaws all classifications against any category of noncitizens. Rather, it is that the non-discrimination requirement of the Civil Rights Act cannot be discarded as a factor in preemption analysis simply because a state law claims to target only immigrants present without federal permission.

189. See, e.g., Fong Yue Ting v. United States, 149 U.S. 698, 724-28 (1893); Chae Chan Ping v. United States, 130 U.S. 581, 589 (1889).

190. See supra note 125 .

191. 169 U.S. 649, 705 (1898).

192. Fong Yue Ting, 149 U.S. at 727 (requiring a non-Chinese, white witness to prove eligibility for a residence certificate).

193. See supra note 142 and accompanying text.

194. See, e.g., Hartford, Conn., Muni. Code ch. 2, art. 21 (2013); Or. Rev. Stat. § 181.850(1) (2011) (stating that law enforcement agencies and political subdivisions shall not "use agency moneys, equipment or personnel for the purpose of detecting or apprehending persons whose only violation of law is that they are persons of foreign citizenship present in the United States in violation of federal immigration laws"); Milwaukee, Wis., General Order 200803 (eff. Aug. 26, 2008); Virginia Beach, Va., Operational General Order 11.10 (eff. May 1, 2007); New Haven, Conn., General Order 06-2 (eff. Dec. 21, 2006); Seattle, Wash., Directive 03- 
public colleges for all state residents; ${ }^{195}$ authorize drivers licenses to every qualifying driver; ${ }^{196}$ allow law school graduates who pass the bar to be licensed as attorneys regardless of immigration status; ${ }^{197}$ or establish universal municipal identity documents available to every city resident. ${ }^{198}$

57 (eff. 2002). By and large, these orders allow local police to inquire into immigration status only after an individual has been arrested for a serious crime or in the course of a criminal investigation.

195. See, e.g., CAL. Educ. Code Ann. § 68130.5 (West 2013); Conn. Gen. Stat. Ann. $\S 10 a-29(9)$ (West 2013). Fourteen states have clear policies allowing undocumented immigrants to pay in-state tuition at state institutions of higher education. Twelve states have statutes allowing anyone graduating from a state high school to claim in-state tuition: Texas, California, Utah, New York, Washington, Illinois, Kansas, New Mexico, Nebraska, Wisconsin, Maryland, and Connecticut. Rhode Island has a policy allowing undocumented immigrants to claim instate tuition enacted by its Board of Governors for Higher Education. Maryland passed a law allowing for in-state tuition for undocumented students as long as they meet certain requirements. In-State Tuition and Unauthorized Immigrant Students, NATIONAL CONFERENCE OF STATE LEGISLATURES, available at http://www.ncsl.org/issues-research/immig/in-statetuition-and-unauthorized-immigrants.aspx (last updated Nov. 28, 2012). In addition, Oklahoma previously had a law allowing for in-state tuition. That law was repealed in 2008, but the Oklahoma State Regents still has the power to enroll a student if he or she meets certain criteria. Map of States with In-State Tuition Laws, NuMBERSUSA, https:/www.numbersusa .com/content/learn/dream-act/map-states-state-tuition-laws.html ("[T]he new law allows the state's Board of Regents to award in-state tuition to illegal aliens who have attended an Oklahoma high school for at least two years and graduated. They must also sign an affidavit [stating] that they are trying to legalize their status or will do so ....").

196. See, e.g., N.M. STAT. ANN. § 66-5-9(B) (West 2013); N.M. CodE. R. § 18.19.5.12(D) (LexisNexis 2013); WASH. REV. CODE ANN. § 46.20.035(3) (West 2013). In addition, thirty-eight states issue drivers licenses to individuals receiving deferred action relief under the Obama administration's Deferred Action for Childhood Arrivals (DACA) program. See Are Individuals Granted Deferred Action under the Deferred Action for Childhood Arrivals (DACA) Policy Eligible for State Driver's Licenses?, NATIONAL IMMIGRATION LAW CENTER, http://www.nilc.org/dacadriverslicenses.html (last updated Apr. 9, 2013).

197. The California bar, with the Attorney General's support, is seeking to allow such licensing, and the issue is currently before both the California and Florida Supreme Courts. See Steve Bousquet, Florida Supreme Court Considers: Can Immigrant Illegally in U.S. Practice Law?, MiAMI HeRALD (Oct. 2, 2012), http://www.miamiherald.com/2012/10/02/3031618/floridasupreme-court-considers.html; Maura Dolan, California State Bar Argues for Law Licenses for the Undocumented, L.A. TIMES (Jun. 19, 2012), http://articles.latimes.com/2012/jun/19/local/lame-immigrant-lawyer-20120619. The docket for In re Sergio C. Garcia on Admission is available at http://www.courts.ca.gov/18822.htm. See also Brief of Amicus Curiae Kamala Harris, Attorney General of the State of California, In re Garcia, No. S202512 (Cal. July 18, 2012), available at http://www.courts.ca.gov/documents/4-s202512-amicus-ca-atty-general-kamalaharris-071812.pdf.

198. At least eight municipalities have some form of municipal ID: Los Angeles, CA; New Haven, CT; Oakland, CA; San Francisco, CA; Trenton, NJ; Princeton, NJ; Asbury Park, NY; Washington, D.C.; and Mercer Co., NJ. Eligibility for drivers' licenses is in flux. Dan Frosch, $A$ New Fight on Licenses for Illegal Immigrants, N.Y. TIMES (Jan. 18, 2012), http://www.nytimes.com/2012/01/19/us/in-new-mexico-a-fight-anew-over-drivers-licenses-forillegal-immigrants.html; Mary Wisniewski, Illinois May Give Driver's Licenses to Illegal Immigrants, REUTERS (Nov. 21, 2012), http://usnews.nbcnews.com/_news/2012/11/21/15333584illinois-may-give-drivers-licenses-to-illegal-immigrants?lite. 
These equality-enhancing measures typically function by declining to inquire into an individual's immigration status. They are designed to put all residents on an equal footing for municipal matters by making immigration distinctions irrelevant for local purposes. The local laws may be adopted to minimize the risk of racial or ethnic profiling by police or other civil servants, ${ }^{199}$ to ensure confidence in community policing, ${ }^{200}$ to remove crippling and demoralizing hurdles that impede young immigrant high-school graduates from accessing educational opportunities, ${ }^{201}$ or to facilitate access to libraries, banking services, and other institutions. Localities may choose such policies to further local interests and public safety. ${ }^{202}$

199. Race, ethnicity, and nationality are typical factors for determining suspicion of alien status. See, e.g., United States v. Brignoni-Ponce, 422 U.S. 873, 875 (1975); United States v. Montero-Camargo, 208 F.3d 1122, 1127 (9th Cir. 2000). For a particularly telling example of local law enforcement using these factors impermissibly, see Letter from Thomas E. Perez, Assistant Att'y Gen., to Bill Montgomery, Cnty. Att'y of Maricopa Cnty., Ariz. (Dec. 15, 2011), available at http://www.justice.gov/crt/about/spl/documents/mcso_findletter_12-15-11.pdf.

200. See e.g., D.C. Mayor's Order No. 2011-174, 58 D.C. Reg. 009083 (Oct. 19, 2011).

In addition to promoting important community policing goals, assistance from immigrant populations is especially important when an immigrant, whether documented or not, is the victim of or witness to a crime. These persons must feel comfortable in coming forward with information and in filing reports. Their cooperation is needed to prevent and solve crimes and maintain public order, safety, and security in the entire community. One of our most important goals is to enhance our relationship with immigrant communities as well as to establish new and ongoing Id. partnerships consistent with our community policing philosophy.

201. For example, on signing the Maryland DREAM Act, Governor Martin O'Malley said: "The more that we do to make the dream of a college education a real opportunity for every child in Maryland, the stronger that makes Maryland." Alina Mogilyanskaya, In Md. Voters' Approval of Dream Act, Hope for Students and Sign for the Nation, CHRONICLE OF HiGHER EDUCATION (Nov. 6, 2012), http://chronicle.com/article/Hope-for-StudentsSign-for/135596/.

202. See, e.g., Statement of Cathy L. Lanier, Chief of Police, Washington, D.C. (Apr. 20, 2007), available at http://newsroom.dc.gov/show.aspx/agency/mpdc/section/4/release/10998/ year/2007.

Our department is responsible for providing police services to everyone in the District of Columbia-equally, fairly, and justly. To help carry out that mission, we have adopted a strategy of community policing - of police and residents working together to fight crime in a partnership of cooperation, respect, and trust. If some of our residents are reluctant to interact with police, because they fear we are there to enforce civil immigration laws, then all hopes for partnership and cooperation are lost, and what really suffers the most is the safety of entire communities. 
Such laws-often referred to somewhat misleadingly as "sanctuary" laws ${ }^{203}$-are designed to reduce the salience of immigration status for local matters. The measures provide that immigration categories and violations should matter only for required federal purposes and not for local decisions (unless mandated by federal law). They decline to apply an immigration-status filter for participation in municipal affairs, for receipt of local services, or for access to local benefits. They may seek to limit the involvement of local entities in sharing immigration information with federal officials and to distance local officials from federal immigration enforcement to the maximum extent permissible. ${ }^{204}$

This category of local policies is not inconsistent with federal law and should not be at risk of preemption on grounds applicable to local enforcement measures. Local governments that reject consideration of immigration-status distinctions are affirmatively furthering the principles of non-discrimination and equality that lie at the heart of the Civil Rights Act. Local or state integration laws enhance civic participation, reduce the risk of discrimination, and promote the equality of immigrants in society. The laws are not merely operating in the interstices of federal immigration enforcement requirements; rather they are supported by the federal value of immigrant equality.

203. The term "sanctuary" risks confusion insofar as it suggests affirmative insulation from or interference with federal enforcement mandates. These ordinances or laws do not afford any formal protection or "sanctuary" from federal enforcement. Rather, they provide that for state or local purposes, absent an express federal duty or prohibition, immigration status will not be pursued or considered. For an excellent cataloguing and discussion of many such laws, see Rodriguez, supra note 9, at 600-05. The term has no single agreed-upon definition. For a range of compilations and definitions see Corrie Bilke, Divided We Stand, United We Fall: A Public Policy Analysis of Sanctuary Cities' Role in the "Illegal Immigration" Debate, 42 IND. L. REV. 165, 180 (2009) (discussing the 2006 Congressional Research Service); S. Karthick Ramakrishnan \& Tom (Tak) Wong, Immigration Policies go Local: The Varying Responses of Local Governments to Undocumented Immigration 10 (2007), http://www.law. berkeley.edu/files/RamakrishnanWongpaperfinal.pdf (finding seventy-one "pro-immigrant" or "sanctuary" ordinances broadly defined). NumbersUSA lists three states-Oregon, Utah, and Vermont-and 142 localities as having some form of "sanctuary law," which they define as any law or policy preventing police from asking about or acting on immigration information in a variety of circumstances. See Sanctuary Laws, NUMBERSUSA, https://www.numbersusa.com/ content/learn/national-security/sanctuary-laws.html. See also About Sanctuary Policies, NUMBERSUSA, https://www.numbersusa.com/content/learn/issues/american-workers/sanctuarypolicy.html.

204. See generally Kristina A. Campbell, Humanitarian Aid is Never a Crime? The Politics of Immigration Enforcement and the Provision of Sanctuary, 63 SYRACUSE L. REV. 71, 111-15 (2012); Rose Cuison Villazor, "Sanctuary Cities" and Local Citizenship, 37 FORDHAM URB. L.J. $573(2010)$. 
This understanding may help address a concern that is sometimes raised to suggest that tolerance of state immigration enforcement measures is necessary to also give states the leeway to adopt immigrant-friendly and immigrant-integration laws. Supporters of sub-federal immigrant integration policies have suggested that a strong federal immigration preemption rule may undermine or eviscerate the capacity of states and localities to welcome immigrants into their communities through positive local initiatives. ${ }^{205}$ The implication is that a robust doctrine of immigration preemption barring local immigration enforcement laws may be a two-edged sword that threatens immigrant-protection laws. Under this view, a presumption in favor of preemption-as I believe Arizona functionally adopts with regard to state enforcement measures ${ }^{206}$ might be seen (mistakenly) as impeding states' authority to enact immigrant-friendly measures.

I believe this worry assumes a narrow conception of preemption that does not take account of the immigrant equality element of federal law. Recognition of the equality component means that local laws advancing immigrant equality are conceptually distinct from laws that target immigrants for enforcement. Local equality-promoting measures affirmatively effectuate the federal equality norm of the Civil Rights Act, whereas state immigration enforcement laws obstruct or conflict with the anti-discrimination mandate. Robust preemption of local enforcement initiatives should not diminish a state's flexibility to experiment with equality measures that further immigrant integration.

\section{Preventing Harassment}

The Civil Rights Act immigrant equality element also finds support in Arizona's anti-harassment analysis. The Court's decision recognized the federal interest in preventing local harassment of foreign nationals. ${ }^{207}$ The basis for that interest is preserving federal

205. See, e.g., Rodriguez, supra note 9, at 567 (arguing that courts should adopt a weaker preemption regime in the immigration context for the purpose of protecting the prerogative of states and localities to enact policies integrating immigrants). $C f$. Pratheepan Gulasekaram \& Rose Cuison Villazor, Sanctuary Policies \& Immigration Federalism: A Dialectic Analysis, 55 WAYNE L. REV. 1683, 1717 (2009) (expressing potential "hesitation with recognizing the validity of sanctuary policies under the preemption doctrine" for fear "that allowing inclusionary measures to survive the preemption doctrine requires similar treatment of exclusionary laws").

206. Guttentag, Immigration Preemption, supra note 11, at 34.

207. Arizona v. United States, 132 S. Ct. 2492, 2506 (2012). 
control over foreign relations. But, like the protection against discrimination, the concern with harassment is focused on the potential consequences of local laws. The reason the laws are deemed inconsistent with federal purposes is that they threaten immigrants with the risk-not the certainty-of harassment or abuse. In that respect, preventing harassment is closely related to avoiding discrimination or furthering equality. All are assessing the threat to federal values by predicting the potential impact on immigrants, albeit based on different rationales.

As Arizona explained, the rationale for prohibiting unsanctioned harassment by local officials is to prevent tensions with other nations if their nationals are mistreated in the United States and to protect Americans abroad from retaliatory actions by foreign governments. ${ }^{208}$ Prohibiting mistreatment is thus derivative of the interest in maximizing federal control over matters that touch on foreign relations. In contrast, the 1870 Act's foundation for nondiscrimination is based on the interest in protecting non-citizens as the end in itself.

Nonetheless, both the civil rights and the foreign relations rationales consider the risk that state laws pose for immigrants. This is a more encompassing view of the federal interest because it extends beyond narrowly looking at Congress's policies on regulating, punishing, conditioning, or blessing the presence of non-citizens in the United States under the immigration statutes. In Hines v. Davidowitz, the anti-discrimination principle of the Civil Rights Act of 1870 and the anti-harassment principle emanating from the foreign affairs power converged when the Court invoked both to strike down the Pennsylvania registration law. ${ }^{209}$

208. Arizona noted that foreign nationals could be harassed as a consequence of SB 1070 . Id. at 2498. The Court explained that "[p]erceived mistreatment of aliens in the United States may lead to harmful reciprocal treatment of American citizens abroad." Id. Central to foreign relations is "the protection of the just rights of a country's own nationals when those nationals are in another country." Id. at 2498-99 (quoting Hines v. Davidowitz, 312 U.S. 52, 64, (1941)). The Court found a threat to federal interests in the risk of "unnecessary harassment of some aliens ... whom federal officials determine should not be removed." Id. at 2506.

209. See Hines, 312 U.S. at 62-66 (providing the anti-harassment rationale); id at 69 ("Our Constitution and our Civil Rights Act have guaranteed to aliens "the equal protection of the laws (which) is a pledge of the protection of equal laws." (quoting Yick Wo v. Hopkins, 118 U.S. 356, 369 (1886))); see also supra notes 119-22 and accompanying text. The congressional debates over the alien provisions in the 1870 Act reflect the close relationship between the two rationales. In advocating for his bill, Senator Stewart cited, among other reasons, the treaty rights of the Chinese and the duty of the United States to prevent harassment and discrimination. Cong. Globe, 41st Cong., 2d Sess. 3658, 3807 (1870). Thus, the federal 
$* * *$

The federal interest in protecting non-citizens against harassment and discrimination erect a framework that tilts in favor of state measures furthering immigrant equality and against measures increasing immigration discrimination. This suggests that states and localities may generally (subject to express, permissible federal prohibitions) elect to disregard immigration status distinctions when they choose, and may enforce immigration violations only as federal law affirmatively permits. This, in turn, reflects a federal scheme that prohibits parochial discrimination and values sub-federal immigrant equality. States retain latitude to innovate and to foster immigrant integration within a broad zone consistent with an immigrant-equality goal. This conception of local autonomy effectuates the "overriding national policies" of the federal scheme. ${ }^{210}$

This is not to suggest that the immigrant equality element of federal law applies mechanically to permit or preempt state laws solely depending on whether they are characterized as enforcement or integration measures-or as "equality" or "discrimination" laws. Preemption necessarily depends on a careful assessment of the actual state statute, its intended and likely effects, and the scope of federal protections, permissions, and prohibitions. My claim is not that the 1870 Act categorically prohibits or allows every kind of state law of one category or another.

My modest ambition is to demonstrate that immigration preemption must take account of the overlooked immigrant equality element that is embedded in federal law. Arizona assertively enforced the immigration control component of preemption. A fuller reading of the federal framework should give equal stature and force to the immigrant equality norm.

prohibition against state discrimination Stewart advanced served both to protect the Chinese and to fulfill treaty obligations.

210. This does not preclude Congress from expressly legislating (if otherwise within its allowable powers) to specify what is consistent with and contrary to federal law. But when congressional purpose is discerned from the broad framework, the immigrant equality norm acts, at a minimum, as the proverbial thumb on the preemption scale. Cf. Young, supra note 2, at 274-75 (discussing the general "thumb on the scale" against preemption). 


\section{CONCLUSION}

The Supremacy Clause mandates fidelity to federal law over conflicting state measures. Judicial enforcement requires discerning congressional purpose to reject state laws that "stand[] as an obstacle to the accomplishment and execution of the full purposes and objectives of Congress." ${ }^{211}$ Defining the federal objectives, though inevitably disputed and inexact, compels courts to identify the appropriate federal interest and legislative framework. For immigration federalism, an assessment of the federal scheme must look beyond the confines of the immigration statute and immigration control. Preemption must include the broad immigrant equality goals embedded in federal law that prohibit state alienage discrimination. The centrality of the Civil Rights Act of 1870 to that endeavor is demonstrated by the scope of the Act and the Supreme Court's recognition of its purpose. As a new generation of state and local immigration measures become subject to scrutiny under principles of preemption and federal supremacy, the importance of enforcing immigrant equality as a core component of federal law grows. The values that equality embraces provide further grounds for questioning state immigration enforcement measures while encouraging local immigrant integration initiatives to flourish.

211. Arizona, 132 S. Ct. at 2501 (quoting Hines, 312 U.S. at 67). 